NBER WORKING PAPER SERIES

\title{
PUBLIC ECONOMICS AND INEQUALITY: UNCOVERING OUR SOCIAL NATURE
}

\author{
Emmanuel Saez \\ Working Paper 28387 \\ http://www.nber.org/papers/w28387
NATIONAL BUREAU OF ECONOMIC RESEARCH
1050 Massachusetts Avenue
Cambridge, MA 02138
January 2021

This paper was presented as the AEA Distinguished Lecture in January 2021. I thank Ulrike Malmendier, Pascal Michaillat, Thomas Piketty, Stefanie Stantcheva and Gabriel Zucman for helpful comments and discussions. Akcan Balkir provided outstanding research assistance. I acknowledge funding from the Berkeley Center for Equitable Growth and the Berkeley Stone Center on Wealth and Income Inequality. The views expressed herein are those of the author and do not necessarily reflect the views of the National Bureau of Economic Research.

NBER working papers are circulated for discussion and comment purposes. They have not been peer-reviewed or been subject to the review by the NBER Board of Directors that accompanies official NBER publications.

(C) 2021 by Emmanuel Saez. All rights reserved. Short sections of text, not to exceed two paragraphs, may be quoted without explicit permission provided that full credit, including (C) notice, is given to the source. 
Public Economics and Inequality: Uncovering Our Social Nature

Emmanuel Saez

NBER Working Paper No. 28387

January 2021

JEL No. H0

\begin{abstract}
$\underline{\text { ABSTRACT }}$
This paper argues that the social nature of humans, absent from the standard economic model, is crucial to understand our large modern social states and why concerns about inequality are so pervasive. A social solution arises when a situation is resolved at the group level (rather than the individual level) through cooperation and fair distribution of the resulting surplus. In human societies, childcare and education for the young, retirement benefits for the old, health care for the sick, and income support for those in need, is resolved at the social level, and through the social state in advanced economies. Social situations are pervasive even outside government and play a significant role in the distribution of pre-tax market incomes.
\end{abstract}

Emmanuel Saez

Department of Economics

University of California, Berkeley

530 Evans Hall \#3880

Berkeley, CA 94720

and NBER

saez@econ.berkeley.edu 
The standard economic model is based on rational and self-interested individuals who interact through markets, yet it is obvious that humans are also social beings who care about and act within groups such as families, workplaces, communities, or nations.

In the standard model, individuals care only about their own consumption independently of social context. Taken literally, the model says that a person struggling at the poverty threshold today gets as much utility as a successful professional two centuries ago when income per capita was less than one tenth of what it is today. ${ }^{1}$ Therefore, economic growth should beat inequality concerns in the long-run. As Robert Lucas once put it "Of the tendencies that are harmful to sound economics, the most seductive, and in my opinion the most poisonous, is to focus on questions of distribution." (Lucas 2004). Yet, in spite of this extraordinary income growth, concerns about inequality and poverty remain alive and well in our advanced economies, implying that relative positions matter to people. ${ }^{2}$ Indeed, the large increase in income concentration in the United States and a number of other advanced economies since 1980 has attracted a lot of attention (see e.g., Piketty 2014 bestseller success) and figures prominently in the policy debate.

The evolution of inequality is illustrated on Panel A of Figure 1 which depicts the share of income earned by the top 10 percent of adults since the early $20^{\text {th }}$ century in the United States and France using comparable methodology. In this paper, I will contrast the United States (often described as a small government free-market economy) with France (with a larger government and more regulated economy). Let us focus first on pre-tax series before taxes and transfers. Both countries show dramatic variations over the century. The US experiences a sharp — and lasting - compression in inequality exactly during World War II at a time of deep government involvement in the war economy. Around 1980, coinciding with the Reagan revolution, inequality starts to increase and has now reverted back to its pre-World War II levels. France also experienced a sharp reduction in inequality during the first half of the $20^{\text {th }}$ century but did not embrace the Reaganian revolution and experienced only a much more modest increase in inequality in recent decades. This figure strongly suggests that political developments play a large role in shaping pre-tax inequality over and above traditional economic forces of technology or globalization (Alvaredo et al. 2018).

Perhaps the most striking fact in modern economies illustrating both our social nature and concerns for inequality is the size of government and the large direct impact it has on the distribution of economic resources. In advanced modern economies, we pool a large fraction of the economic output we produce through government. In the richest countries today, taxes generally raise between 30 and 50 percent of national income and are used to fund not only public goods needed for the functioning of the economy but also a wide array of transfers back to individuals both in cash and in-kind. Even though modern economies generally allocate the fruits of production to workers and owners through a capitalistic market system with well-defined property rights, as societies, a significant fraction of market incomes, typically between one third and one half is shared

\footnotetext{
${ }^{1}$ The Maddison project gathers long-term growth statistics and shows that advanced economies experienced a more than 10-fold increase in GDP per capita since the industrial revolution of the mid- $19^{\text {th }}$ century (Maddison 2007).

${ }^{2}$ A wide literature has documented relative well-being effects (see e.g., Luttmer 2005 and most recently Hviberg, Kreiner, and Stantcheva 2020 for systematic surveys).
} 
(i.e., effectively "socialized") through government. Panel B in Figure 1 shows how the tax burden (including all taxes at all levels of government) is distributed across income groups in 2018 in the United States and France. In both countries, the tax system is approximately a proportional tax that takes the same percentage of pre-tax income from each group with some progressivity over most of the distribution and some regressivity at the top. In France, tax rates are almost 20 points higher than in the US throughout the distribution, but it is worth re-emphasizing that a tax rate of almost 30 percent in the US is still a significant share of the economy.

While a proportional tax does not affect inequality, government spending does reduce inequality substantially. Many government transfers, such as universal health care insurance or public education, are allocated on a per-person basis. Others are targeted to lower earners (such as Medicaid health insurance in the United States). Panel A in Figure 1 illustrates the direct equalizing impact of taxes and government spending on inequality by depicting top 10 percent income share after subtracting all taxes and adding all transfers. This share is substantially below the pre-tax income share especially over the last 50 years when government is bigger (see below). Even though US inequality is almost as high now as it was in the early $20^{\text {th }}$ century on a pre-tax basis, it is still substantially lower on a post-tax basis. For France, inequality on a post-tax basis today is close to its all-time low. The total equalizing effect of government is much wider than depicted on the figure as public policies, such as universal public education, also have a large positive and equalizing impact on pre-tax incomes.

The standard economic model of self-interested agents who interact through markets generates efficiency under classical competitive assumptions. Given the technology and resources constraints, there is no way to reorganize from a market equilibrium to make everybody better off. The economy that arises from such a complex web of market interactions generates the illusion of sociality even though sociality is not part of the model. As Margaret Thatcher put it for a wide audience: "Who is society? There is no such thing! There are individual men and women and there are families and no government can do anything except through people and people look to themselves first." (Thatcher 1987). Public economists have worked primarily within this standard framework to explain (or criticize) why we nonetheless observe such large governments in practice. Government intervention is traditionally justified in two domains.

First, there can be market failures if the standard competitive assumptions do not hold for example because of externalities, market power, or asymmetric information. Such situations can often be addressed with a government intervention that can restore efficiency and sometimes even create a Pareto improvement. For example, corrective taxation can be used to properly price externalities and get the economy back to market efficiency. While such government interventions to address market failures are broadly supported by economists, they can hardly justify the very large size of governments we observe.

Second, public economists justify direct redistribution with taxes and transfers as a way to increase social welfare, generally measured as the straight sum of individual utilities - the famous utilitarian criterion. Because marginal utility of consumption decreases with income, redistributing resources from high earners to low earners increases total utility, a point originally made by Edgeworth (1897). But because 
individuals care only about themselves, they view taxes as reducing their gain from work and hence might work less. This creates an equity-efficiency tradeoff that is resolved by the optimal income tax analysis that Mirrlees (1971) launched. This second aspect is more controversial among economists because it requires introducing a social welfare function that is outside the standard framework. In most interpretations, this social welfare function reflects the views of society embodied into a government that chooses the tax system. Another interpretation, easier to embed in the standard framework, is that self-interested individuals would want some redistribution as insurance against the risk of being poor if such insurance could be obtained before knowing your position on the economic ladder-behind the veil of ignorance as Rawls (1971) famously put it. The tax and transfer system effectively provides such insurance. However, as we shall see, the redistribution done by government is primarily in-kind or targeted to specific groups and therefore quite different from the across the board redistribution predicted by standard utilitarian optimal tax theory.

In this paper, I want to argue that the social nature of humans, absent from the standard economic model, is crucial to understand our large modern governments and why concerns about inequality are so pervasive. A social solution arises when a situation is resolved at the group level-rather than the individual level. For example, providing classical public goods, such as national defense, funded through taxation of private incomes is a social solution. Generally, a social solution requires cooperation (such as obeying tax laws) and fair distribution of the resulting surplus (accepting how the public good will be financed through taxes). Humans have been shaped, through many millennia of evolution, to work together for the benefit of the group. This extraordinary ability to cooperate and find social solutions is pervasive, even outside government which is just the most obviously visible form of social cooperation in our modern economies. I will illustrate this through a number of examples taken from various fields of economics: public economics, labor economics, behavioral economics and lab experiments. The ideas presented here draw upon large academic literatures in many fields of economics and the social sciences, of which I know and have cited but a small subset, primarily the readings that have influenced me the most. The empirical evidence shown is voluntarily illustrative rather than comprehensive so as to present ideas in the simplest way.

In human societies, childcare and education for the young, retirement benefits for the old, health care for the sick, and income support for those in need, is to a large extent resolved at the social level rather than the individual level. This was traditionally done informally through the community and the family and is now achieved through the modern social state in advanced economies. Even though an individual solution through markets is theoretically possible, in practice, it does not work well without significant institutional or government help. Human societies are good at providing education, health care, retirement and income support even though individuals are not. However, such social aspects are quite different from a general willingness to redistribute out of utilitarian principles. In all advanced economies, income support is primarily targeted to groups unable to work and delivered in-kind rather than cash. Income support to groups expected to work and support themselves always raises concerns and hence is generally paired with help or push to find work. Societies dislike having to face the equity- 
efficiency tradeoff and hence try to circumvent it rather than embracing it as standard optimal tax theory posits.

The standard concern is that the social state with its large taxes and transfers might discourage labor supply. However, the social state also intentionally reduces labor supply by design through various regulations: child labor prohibitions and compulsory education limit work by the young, retirement benefits sharply reduce work in old age, overtime hours of work regulations and mandated paid vacation (e.g. 5 weeks in France) reduce work across the board. This implies that labor supply should be seen partly as a social choice with society having disutility of labor for the very young, the old, and very long hours with no vacation break.

Social solutions are common even outside government, including within private firms, and play a significant role in the distribution of pre-tax market incomes. Almost any work activity requires cooperation in production that cannot be mediated solely through markets. Situations with cooperation in production and ensuing distribution of surplus are common in all human societies. This has shaped us to be both good at cooperation and very sensitive to inequality. Even in modern economies, rigid compensation rules for distributing the fruits of production are a pervasive way to resolve the distributional issue. This also means that there is more scope to address inequality at the pre-tax level than economists generally believe. Pre-tax distribution of production between workers and owners has indeed been historically the place where inequality is shaped, with government setting the rules of the game and hence having a very large but indirect impact.

The paper is organized as follows. In Section I, I discuss how government redistribution evolved through history to what it is today, revealing our social nature. In Section II, I describe how the modern social state works. In Section III, I emphasize that labor supply choices have a very large social component through social state regulations. In Section IV, I show that this social nature permeates beyond government and helps understand why inequality concerns are so pervasive. Section V concludes.

\section{How Social Redistribution Evolved to What It is Today}

\section{A. Pre-history. Hunter-gatherers}

Homo sapiens is 200,000 years old and up to 12,000 years ago, humans have been organized in hunter-gatherer societies (Harari 2014). Therefore, the hunter-gatherer form of social organization covers 94 percent of human history, and over 99.4 percent of homo history if one considers our hominins hunter-gatherer ancestors that go back at least 2 million years (Tattersall 2012). A handful of hunter-gatherer societies remain to this day and have been studied extensively by anthropologists with various studies analyzing specifically their economic organization. ${ }^{3}$

Hunter-gatherer societies are generally small-typically less than 100 people. They are also fairly egalitarian as they have minimal private wealth and leaders with

\footnotetext{
${ }^{3}$ Malinowski (1922), Mauss (1925), and Firth (1939) are classic studies. Economic anthropology is an active field of research within anthropology/sociology but with modest impact (so far) on mainstream economics. Thurnwald (1932) and Sahlins (1972) are influential economic studies of early societies and Wilk and Cliggett (2007) for a modern textbook on economic anthropology.
} 
limited power. Private wealth is minimal because the land and its natural resourcesanimals for hunting and plants for gathering - is communally held. Furthermore, nomadism drastically limits the accumulation of private housing, goods, and tools (Woodburn 1982). Leaders have limited power because the rank and file vigilantly keep leaders from becoming despotic through a reverse dominance strategy as hypothesized by Boehm (1999). As he summarizes it: "All men seek to rule, but if they cannot rule they prefer to be equal." (p. 105). A good analogy familiar to the reader is the modern academic department in universities: faculty are protective of their independence and do not tolerate a chair with excessive power.

Community cooperation and sharing is common for many tasks. As is well known, humans were able to hunt (sometimes to extinction) big and dangerous game through group cooperation (Diamond 1997). There are sharing norms for the produce of hunting through customs and reciprocity rather than markets. The rationale for such norms is that this avoids distributional conflicts. Distribution among the full community is common and also makes sense in a setting with limited storage. In contrast, gathering is an individual task and is typically only shared within the family not the community (Thurnwald, 1932, p. 266). Therefore, there is generally norm-based sharing for cooperative work but not for individual work.

Humans' life cycle means that the young, the old, and the sick cannot support themselves and hence need support from others. In hunter-gatherer societies, they are taken care of through a mix of family and community support. Presence of the elderly has been documented in the fossil record among ancestors of homo sapiens and exploded over the last 30,000 years (Caspari and Lee 2004). This implies that the old were cared for in prehistorical human societies. They also helped with childrearing (the grandmother hypothesis proposed by Williams 1957). Children are generally raised in village groups. Children play and learn and do not start working until adolescence. ${ }^{4}$

Therefore, the pooling of economic resources among hunter-gatherers is fairly high and probably around 50 percent. This rough estimate can be obtained as follows. Wealth in the form of land and its natural resources is communal and hence so is the implicit capital income estimated to be 25 percent of output by analogy to pre-industrial economies. ${ }^{5}$ Labor income, 75 percent of the remaining output, is generally pooled for hunting but typically not gathering, firewood collection and cooking. Assuming that $1 / 3$ of work is hunting where product is pooled, this adds 25 percent of output to the shared pool. ${ }^{6}$ Similar to nations today, there is pooling of resources within the group but not across groups. Instead of pooling ressources, different groups trade goods and sometimes fight over the control of natural resources (Thurnwald, 1932).

How are hunters motivated to hunt if the produce is communally shared? From an evolutionary perspective, if cooperation gave hominids and then humans an edge, it

\footnotetext{
${ }^{4}$ For example, Biesele and Howell (1981) analyze the contemporaneous !Kung hunter-gatherers from South West Africa and discuss aging and child rearing aspects.

${ }^{5}$ Piketty and Zucman (2013) and Piketty (2014) show that capital income and wealth were mostly derived from land but were quantitatively as important as in our advanced economies in $18^{\text {th }}$ century France and United Kingdom (relative to the size of the economy).

${ }^{6}$ This is naturally a very rough approximation in such a vast anthropological context. Besides food production, there are other labor tasks some of which are communal like warfare, some of which are private such as making household artifacts.
} 
makes sense that motivation cannot be solely self-interested and that individuals value working for the group (Gintis et al. 2003, Henrich et al. 2004). ${ }^{7}$ Laziness is indeed seen as an anti-social behavior (Thurnwald 1932). As Polanyi (1944, p. 270) summarized the anthropological work of Malinowski, Thurnwald, and Firth on primitive societies: "the usual incentives to labor are not [individual] gain but reciprocity, competition, joy of work, and social approbation." Again, these motivations for work are familiar to the modern academic researcher. Monetary gain is the not our immediate motivation while reciprocity when working in a team with co-authors often is. Competition with other teams to produce the most influential research is clearly a motivator. Joy of work is needed to be able to sustain long hours of work for many years. Social approbation in the form of reputation among peers clearly matters to us as well.

\section{B. History. The Coercive State}

About 12,000 years ago, agriculture transformed human societies into sedentary communities that sometimes became socially stratified as a ruling class could take control (Thurnwald 1932). In the most fertile areas-Mesopotamia, the Nile valley, the Yangtze river in China-formal city states arose about 6,000 years ago. They were organized as despotic kingdoms, they invented taxes and writing as administrative tools for the new formal state. Writing defines the beginning of history and was initially invented for the administration and in particular the tax administration of the state. They also used forced labor, with various gradations from serfdom to slavery. The goal was to serve and enhance the power of the state-often identified with the ruler or ruling family - rather than the welfare of the community. Taxes and forced labor funded the construction of monumental cities and infrastructure, defense and warfare, law and order, and the other functions of the administrative state, i.e., the regalian public goods. Health decreased due to risk of relying on a single crop and infectious diseases in dense populations. This made the early city states fragile (Scott 2017).

These despotic communities are much more unequal both politically and economically than earlier hunter-gatherer communities (Boehm 1999). Indeed, wealth and political power are closely correlated as chiefs or kings rule and have control of the land and infrastructure. ${ }^{8}$

Coercive states slowly overtake the hunter-gatherer and sedentary agricultural communities in the western world as well as in many parts of Asia and South America, and become the most common form of social organization up until modern democracies start emerging a few centuries ago such as the United States and France in the late $18^{\text {th }}$ century. Democratization itself is a slow process as many groups are initially excluded. Women could not vote until 1920 in the US and 1945 in France. Many countries excluded the poor from voting with poll taxes, literacy or property ownership requirements. Emerging democracies could also be extremely coercive against specific

\footnotetext{
${ }^{7}$ Social species have evolved to cooperate in production. In the most extreme cases, such as ants or bees, each individual works for the group implying an almost 100 percent tax rate. Humans are in between purely social species and purely individualistic species (Wilson 2012).

${ }^{8}$ To this day in autocratic states, wealth and political power are often closely aligned as the autocrat has the power to redistribute wealth toward himself and his family (Acemoglu and Robinson 2012).
} 
groups either internally - such as Native Americans as the frontier expanded or enslaved African-Americans until 1865, or externally through colonies - the French and British empires undemocratically ruled over about 30 percent of the world population in the early $20^{\text {th }}$ century (see Piketty 2020 for an extended analysis).

In coercive states, social support for the young, the elderly, and the sick shrinks down to the family rather than the community although some institutions, most notably the church, do provide some education, health care, and indigent support for those with no family support. For the vast majority of the population, education is minimal. For the wealthy few, education is generally paid for by parents. Child labor becomes very common. People usually keep working in old age even when their productivity - and hence their earnings - fall (Minois 1989). When they can no longer support themselves, they are generally supported by their children as savings and accumulation of wealth is limited to a small elite. For the few countries for which we have data, the bottom 90 percent of the population owns very little (Piketty 2020). Health care is rudimentary and the sick generally rely on their families to support them while they cannot work.

Forced labor slowly decreases and is abolished in most Western countries a few centuries ago although slavery lasts into the $19^{\text {th }}$ century in their colonies, and in the newly independent United States of America.

The level of taxes - even when including local taxes - is typically low, less than 10 percent of output in all western countries for which we have data all the way until the beginning of the $20^{\text {th }}$ century (Piketty 2020, Chapter 9). Such a low level of taxes can only fund regalian public goods (administration, law and order, defense, infrastructure) but not the social state. Furthermore, the tax system is typically regressive as taxes are either taxes on consumption, rudimentary poll taxes and property taxes on real estate, or flat taxes on agricultural output (Ardant 1971).

Throughout this long history, the challenge of despotic states is to extract revenue to enhance the power of the state without generating tax revolts (Weber and Wildavsky 1986). As Colbert, the finance minister of Louis the XIV of France, put it: "The art of taxation consists in so plucking the goose as to procure the largest quantity of feathers with the least possible amount of hissing." Taxes are low because enforcement is difficult in a mostly informal economy and tough enforcement can backfire in the form of tax revolts. This view of taxes funding a coercive state still has resonance today among libertarians particularly in America which they view as a democracy founded through a tax revolt against the British crown "No taxation without representation". 9

\section{The Rise of the Social State in the $20^{\text {th }}$ century}

An extraordinary transformation of our societies takes place during the $20^{\text {th }}$ century. In advanced economies, the size of the government measured by tax revenue to national income increases from less than 10 percent to levels between 30 and 50 percent. ${ }^{10}$ Panel A in Figure 2 (taken from Piketty 2020) illustrates this for a few countries: the United

\footnotetext{
${ }^{9}$ As we mentioned above, America was at first an incomplete democracy. Before then, American colonies had a lot of autonomy in setting their tax systems with regressive taxes in the South but incredibly progressive taxes - for the time - in the North (Einhorn 2006).

${ }^{10}$ Flora (1983) gathers the most extensive historical statistics and OECD 2020a covers the contemporary period since 1965 .
} 
States, the United Kingdom, France, and Sweden. In all these countries, the tax ratio is low (below 10 percent) and flat until World War I, increases until around the late 1970s, and then is roughly stable thereafter. The exact timing of the tax increases and the final level of the ratio differ across countries with France and Sweden stabilizing around 50 percent and the United States around 30 percent (and the United Kindgom around 40 percent).

Panel B in Figure 2 (also created in Piketty 2020) depicts the evolution of the composition of government spending (relative to national income) in Europe (average of France, Germany, Sweden, and the United Kingdom) since 1880 . Up to the early $20^{\text {th }}$ century, the bulk of government spending is devoted to regalian public goods as we discussed above. The growth of government over the $20^{\text {th }}$ century is almost entirely due to the growth in the social state that provides education and childcare support for the young, health care for the sick, retirement benefits for the old, as well as an array of income support programs for groups in need such as the disabled, unemployed, or the poor. Essentially, the social state provides support for those who cannot provide for themselves because they are young, old, sick, or otherwise unable to earn a living. Let us review the historical development of each pillar in turn.

Education. Government tax funded and compulsory education is the pillar of the social state that develops first. The motivation is in part nation building and hence fits within the framework of the coercive state building its power. But the social aspect of universal human development and opportunity is also part of the motivation.

Prussia and Austria were the first to adopt compulsory schooling in the mid- $18^{\text {th }}$ century (Van Horn Melton 1988). America was also a precursor in mass education but following a decentralized process (instead of nation building). Massachusetts was the first US state to enact compulsory education in 1852 (and had already achieved a high level of schooling when it was still a British colony). Mississippi was the last state to adopt compulsory schooling in 1917.

Historically, mass education is always government driven through a combination of government funding (at all levels including higher education) and compulsory schooling (for primary and then secondary education). Meyer, Ramirez, Soysal (1992) provide an empirical analysis of the development of mass education through nation states.

Let us illustrate this on Figure 3. Panel A in Figure 3 shows that in the early $19^{\text {th }}$ century, Prussia and the United States already had school enrollment rates at age 5-14 around 2/3 substantially higher than other countries. France catches up slowly over the $19^{\text {th }}$ century. Slavery in America also imposed school prohibitions on the enslaved so that the school enrollment rate of black children was minuscule before the civil war. After the civil war ends, black children enrollment rates shoot up to over 50 percent by 1880 , one of the fastest increases ever seen and showing the enormous power of the state in restricting or promoting education. Black children enrollment increased more slowly in the Jim Crow period of discrimination after 1880 and would not catch up to whites until after World War II.

Panel B depicts various $20^{\text {th }}$ century experiences showing that compulsory schooling can have dramatic impacts quickly. The most extreme case is soviet Russia that achieved quasi-universal enrollment by 1940 from a level around 40 percent in 1920 . 
Education was a way to both indoctrinate young minds and develop the economy. The communist experiences mix the coercive state-perhaps in its most extreme form under Stalin in the Soviet Union and in North Korea still today-and the social state. Asian countries which experienced fast economic growth over the $20^{\text {th }}$ century also had very proactive education policies (with mass education likely fueling economic growth, Easterlin 1981). Panel B shows a sharp increase for Korea in the late 1940s and Indonesia in the 1970s after they finally adopt universal compulsory schooling (but starting from pre-existing high bases of 60 percent). Mass education requires mobilization to build schools and train new teachers, a process that takes years if not decades after enactment (see Duflo 2001 for an analysis of the Indonesian experience).

Retirement. Retirement support is the pillar of the social state that generally develops second. Retirement programs first developed privately through negotiations between large employers and unions, an indication that workers need institutional help to provide for their retirement. ${ }^{11}$ Public retirement programs sometimes grew out of such private retirement programs through a general mandate. Germany was the first country to introduce such a general mandatory public retirement system in 1889 under Bismarck. Public retirement programs sometimes developed as a retirement benefit aside from or on top of private retirement programs as Social Security in 1935 in the United States (Costa 1998).

Before public retirement programs existed, a large fraction of the elderly was working (80 percent of men aged 65 or more were gainfully employed in the United States in the late $19^{\text {th }}$ century, see Figure 5 below). The elderly who could no longer work enough to support themselves had to rely on family support. Public retirement systems were a way to provide social insurance through the state instead of relying on selfinsurance or family insurance.

Health care. Like retirement benefits, health care benefits start with private arrangements between employers and employees that then get mandated by the state. The earliest program started again in Germany in 1883 under Bismarck to cover workers. Such employer related systems developed in most Western countries in the early $20^{\text {th }}$ century. Universal health insurance expanding coverage to non-workers started after World War II with the United Kingdom launching first its National Health Service in 1948, and spreading quickly among almost all advanced economies, the United States being the notable exception. In the early $20^{\text {th }}$ century, health care was a small fraction of the economy. But today, health care is about 10 percent of the economy in OECD countries and about 18 percent in the United States (OECD 2020c). Therefore, health care is now a very large component of the social state (Figure 2, Panel B).

Income support. Income support programs have a long history with tension between offering support to those in need and concerns about discouraging work. As a result, many programs start as narrow programs targeting groups deemed unable to support themselves such as widows with children (at a time when mothers were not expected to work outside the household), the elderly or the disabled (before retirement programs

${ }^{11}$ Laibson (2018) AEA distinguished lecture was devoted to this phenomenon of private paternalism of employers on behalf of their employees from a behavioral economics perspective. 
existed), or the unemployed. Programs supporting those out-of-work often had a "workfare" component requiring recipients to do some work for the government to receive support such as in the Poor laws in England (Lindert 2004).

A large literature has discussed why the social state emerges in the $20^{\text {th }}$ century. It is likely that democratization replacing earlier coercive authoritarian states led the population to demand help through the social state (see e.g., Acemoglu and Robinson, 2000; Lindert 2004). Looking at history (since the beginning of writing), the modern social state appears as a unique and very recent historical development (150 years old) while the coercive state is the norm throughout history (the preceding 3000-5000 years) with still a number of autocratic states existing to this day. However, extending the time frame back into our long pre-history and its social communities, the modern social state starts to look more like a homecoming - adapted to the modern world and economy to be sure - rather than a radically new, and hence perhaps fragile, development.

\section{The Four Pillars of the Social State today}

The social state raises a puzzle for the standard economic model. Rational individuals in a market economy with functioning credit markets should be able to largely manage on their own. The young (or their parents) can borrow to pay for their education if this is a worthy investment. Health care is largely a private good for which people can buy insurance. Workers can save for their retirement anticipating that their work ability will decline with age. Finally, people can also dip into their savings whenever they face a temporary income loss such as unemployment.

Economists traditionally justify social insurance by focusing on market failures such as asymmetric information leading to credit failure or insurance failure. However, the resulting solutions: guaranteed student loans for education so that anybody can borrow for education, or mandates for health insurance to deal with adverse selection death spirals, or mandatory annuitization of retirement savings to make sure retirees never run out of savings, are much lighter interventions than what actual social states do. More radically, the field of behavioral economics has shown that individuals fail to behave as in the standard model particularly in circumstances that involve the time dimension that are crucial for education investment, health insurance, or old age or buffer stock savings (see Thaler 2015 for description of the emergence of this young field).

Looking back at the deep history we have sketched in the previous section, it is easy to see the common theme between community support of hunter-gatherer societies, family support in coercive state societies, and the social state of modern social democracies. It is worth reviewing briefly the current structure of the four pillars of the social state to understand its logic and why the standard economic model solution does not work well in practice.

\section{A. Education.}

As discussed above, mass education of modern times is always government driven through a combination of compulsory schooling (for primary and then secondary education) and government funding (at all levels including higher education) generally 
taking the form of direct government provision of schools and teachers. In OECD countries, education is always primarily government funded and often overwhelmingly so (OECD 2020b).

If education is compulsory, government funding must follow as low-income families would not be able to afford to pay for it at full cost. This is because education requires highly qualified labor - teachers. This remains the case today as it was in the $19^{\text {th }}$ century as teachers are always skilled workers and the technology of education has not changed much. If a teacher is paid three times the average working-class earnings and can teach 20 students, the cost per school age kid is 300/20=15 percent of working-class earnings prohibitive for many families especially large ones. Therefore, mass education is highly redistributive on a direct basis: every child gets education while tax funding is approximately proportional to income. Education also has enormous indirect redistributive effects by giving opportunities to succeed economically to children from disadvantaged backgrounds.

Higher education is not (yet) compulsory but its capacity is built through public universities as private universities serve only a small fraction of students in advanced economies (OECD 2020b). Even in the United States where private higher education is large, three quarters of students attend public institutions (National Center for Education Statistics, 2020). Therefore, the government essentially controls the supply side. Higher education is also highly subsidized as tuition costs paid by students are only a fraction of the real costs of higher education (and in many countries in Europe such as France, tuition costs are almost zero). Even though higher education is an individual choice, at the aggregate level, it looks like a government choice. One striking example comes from the United States GI bill after World War II that paid for the higher education of veterans and dramatically boosted college education of men (using women as a control group) (Stanley 2003).

Why not have students or their families pay directly for education or borrow with student loans as a standard economic model would recommend? The experience of student loans in the United States shows that they become an unbearable burden for a significant fraction of borrowers. There are several reasons for this. Attending college is not a guarantee to get a degree, let alone get a good paying job afterwards. Furthermore, handling debt is challenging for many as behavioral economics has shown. This forced the government to provide relief ex-post (Baum 2016).

Aside from funding, why not have for-profit education instead of having public institutions provide education? The United States has indeed experienced a surge in forprofit higher education institutions as state funding for public institutions has retreated. The evidence suggests that students can be lured into high cost, low quality for-profit schools (Deming, Goldin, and Katz 2012). This problem is exacerbated when for-profit schools put more weight on profits than service after take-up by private equity (Eaton, Howell, and Yannelis 2020). This is a striking failure of the market that arises because students are not able to assess perfectly the value and cost of education offers (Akerlof and Shiller 2015 develop this aspect of "consumer failures" more generally).

In sum, education is largely decided at the social level, not the individual level.

\section{B. Retirement Benefits.}


The elderly lose their ability to work and hence support themselves with their earnings. The standard economic solution is that workers should save for retirement (the famous life cycle model of Modigliani). A large body of work in behavioral economics shows that, in contrast to what the standard model posits, individuals are not able to save on their own and invest wisely (see e.g., Thaler and Sunstein 2009 for an overview). Indeed, before retirement programs existed, family (or community) support, not saving, was the main source of support as we discussed above.

Public retirement programs are mandatory and funded by taxes. They are typically introduced as pay-as-you-go systems where taxes on workers immediately pay for the pensions of retirees, replacing the former pay-as-you-go family-based system where children take care of their elderly parents. Instead of having to support their elderly parents, adult children pay taxes to fund retirement benefits. Social insurance also allows to pool risks much more effectively than family insurance.

Benefits are generally related to lifetime earnings so that the public retirement system is generally not highly redistributive from a life-time perspective (see e.g. Brown, Coronado, and Fullerton 2009 for a US analysis) but it is highly redistributive from a cross-sectional perspective: elderly retirees with no earnings get support from workers with earnings.

Even the most radical privatization reforms - as in Chile - maintain mandatory contributions. Even private employer pension plans are either mandatory (such as the traditional defined benefit employer pension plans in the US) or highly encouraged through enormous price incentives (such as the 401(k) employer matches in the US) or defaults (being enrolled automatically in 401(k) plans upon hiring which have enormous impact on participation even in the medium term, Madrian and Shea 2001). Therefore, retirement programs, even when they come closest to mimicking the standard lifecycle savings model, need a heavy institutional hand to steer individuals in the right direction.

Therefore, the problem of retirement is also resolved at the social level, not the individual level.

\section{Health Care}

All advanced economies provide universal health care insurance with the United States being the unique exception in leaving about 10 percent of its population uninsured. Health care costs have become large (10 percent of national income on average in the richest countries) due to enormous progress in medicine (OECD 2020c). Hence, tax funding is the norm as lower income families would not be able to afford the full cost. Therefore, universal health insurance creates significant redistribution by income and also of course by health and health risk status.

One important question is why health care quality is the same for all in such universal health care systems (at least as a principle not always realized in practice). Why isn't health insurance offered in grades with cheap insurance covering only the most costeffective treatments? Probably because humans are willing to spend a lot of resources to save a specific live, i.e., an actual person with a condition that can be treated. ${ }^{12}$ This is

\footnotetext{
${ }^{12}$ Economists have noted that societies are willing to spend a lot more resources to save an actual life than to save a statistical life (such as reducing accident risk through better safety). See e.g. Gruber (2016, Chapter 12).
} 
likely a consequence of our social nature shaped by evolution: taking care of the sick or the injured was helpful for group survival. This makes withholding treatment to the poorly insured socially unbearable. In the US, hospitals are obliged to offer emergency care to all patients, even those without insurance and unable to pay. ${ }^{13}$ Of course, on top of this, adverse selection provides a strong standard rational for mandating health insurance.

Even in the US where private insurance covers slight more than half of the population, it is primarily offered through employers which are now mandated to offer it (if they have 50 or more fulltime employees). This mandate is economically equivalent to forcing each insured worker to pay the full cost of the insurance regardless of earnings. This is a crushing and unbearable burden for low paid and insured workers (Saez and Zucman 2019 describe it as a privatized poll tax and Case and Deaton 2020 discuss the labor market impacts).

A recent literature has also shown strong evidence of behavioral effects in health care choices particularly in the US context where choice is most extensive (see Chandra, Handel, and Schwartzstein 2019 for a recent survey). People make mistakes in healthcare utilization and treatment choices. Copayments and deductibles lead consumers to reduce demand for high-value care. This may explain why universal health care systems have low copays and deductibles and why health care decisions for patients are made primarily by health care professionals. Like for education, the difficulty for users to understand and navigate health care choices implies that the market does not necessarily deliver efficiency. In sum, the problem of health care is also primarily resolved at the social level rather than the individual level.

\section{Income Support}

Income support programs are obviously a social level form of help for people in need. They are targeted to specific groups such as the unemployed with unemployment benefits, the disabled with disability benefits, the elderly poor with minimum old-age benefits, and children in poor families (with family benefits such the refundable tax credits and traditional welfare for single parents in the US). Unconditional means-tested support is generally modest and most often in-kind (such as housing or nutrition support) and combined with job training help. For example, even in France, with its generous social state, a single adult with no resources would receive 560 Euros/month in cash as of 2020 (Revenu de solidarité active). ${ }^{14}$ This cash amount is only about 17 percent of average income per adult in France. But it is still over three times as high as the meager \$200/month in SNAP (formerly food stamps) benefits a single adult with no dependent in the US can get (the only form of quasi-cash means-tested transfer available to this group).

Therefore, there is a widespread social view that people who are expected to work and support themselves should be not be supported by the community. Everywhere, there is strong social reprobation against "free loaders" who could work and support themselves but decide to live off government support (Lindert 2004 provides historical

\footnotetext{
${ }^{13}$ In practice, health insurance cost in US private insurance varies primarily based on deductibles and copay and not quality of care.

${ }^{14}$ This can be combined with various in-kind support for housing, utility costs, or public transportation.
} 
context; Saez and Stantcheva 2016 present survey evidence). This is why income support is concentrated among groups unable or not expected to work such as the unemployed, the disabled, the elderly.

This feels very different from a utilitarian optimal tax and transfer system that explicitly trades off equity (redistribution to the poor) with efficiency (some loss of output due to reduced incentives to earn) (see Piketty and Saez 2013 for a survey). Instead income support tags recipients who are not expected to work to avoid the equityefficiency tradeoff (Akerlof 1978).

But our innate aversion to free-loaders can be interpreted as a way to detect the presence of behavioral responses and adjust redistribution with better targeting or with a better design (more incentives to work, help finding work, or less generous benefits). In other words, the public processes efficiency costs through a fairness lens ("free-loaders take advantage of the system", "beneficiaries would be destitute without help"). Stantcheva (2020) shows indeed that distributional and fairness considerations are more important than efficiency considerations when the public reasons about taxes and transfers.

\section{E. Social Group Scope}

While we have seen that pooling of resources through taxes and transfers is very large at the level of the nation (and sub-national governments in decentralized countries), it is striking how small transfers are across countries. Direct foreign aid from rich countries toward developing countries is modest (around .2 percent GDP in the United States and always below 1 percent anywhere else). It is targeted to crises (such as disaster relief), security (defense spending in the context of alliances), and development aid (a substantial portion of which runs through international organizations such as the World Bank or the International Monetary Fund). In US public opinion polls, foreign aid is often the least popular item of government spending (e.g. Pew Research Center 2019). Even in the European Union (EU), an old and deep community of independent nations, the common budget is only 1 percent of the EU economy (and hence minuscule relative to the government budgets of each nation member). Direct transfers across EU countries, even in the context of severe crisis such as the financial crisis of 2009 when Germany directly bought Greek public debt, quickly become controversial.

It has also been noted that the social state is smaller in countries fractionalized along ethnic or religious lines (see Alesina and La Ferrara 2005 for a survey on the economic effects of fractionalization). For example, Alesina and Glaeser (2004) argue that this is the main reason why the US has a smaller social state than European countries. Alesina, Miano, and Stantcheva (2018) show through surveys that the public dislikes redistribution toward immigrants and that emphasizing the presence of immigrants reduces support for redistribution.

All this evidence shows that the scope of the social group matters greatly. Humans are willing to pool resources with the social group they identify with but typically not others, another striking piece of evidence demonstrating our social nature (as opposed to universal utilitarian principles). The nature of the group can vary depending on situations and is also malleable. For example, the rise of the social state was in large part replacing family support by nation state support in specific domains. 


\section{The Social State and Labor Supply}

The main critique leveled at the large modern social state is that it might discourage work and hence depress economic activity. Indeed, in the standard economics model, labor supply reduces utility and the sole motivation for work is individual gain. Therefore, taxes and transfers can reduce labor supply. An enormous empirical literature has shown that this model has indeed some relevance (see Pencavel 1986 and Blundell and MaCurdy 1999 for classic surveys). Estimated labor supply responses are generally-but not uniformly - fairly modest for groups strongly attached to the labor force (such a prime age males) but can be large for groups less attached such as the elderly (Gruber and Wise 1999), secondary earners especially when women were less attached to the labor force (Blau and Kahn 2007), or single parents (Meyer and Rosenbaum 2001).

Taking a broader view though, social determinants of labor supply become readily visible. First, the social state has indeed reduced labor supply along various dimensions (youth labor, old age labor, and long hours) but it has done so intentionally by design and regulation and not as an unintended consequence. Second, social norms also affect labor supply (e.g., whether mothers should work outside the household).

To give a broad level view, Figure 4 depicts the employment rate (people working divided by population) by 5-year age bins in the United States and France in 2019 using OECD statistics for men in Panel A and women in Panel B. ${ }^{15}$ Employment rates are similarly high in both countries in prime age (25-59) and actually slightly higher in France for women. But employment rates are substantially smaller among the young and the old in France. This strongly suggests that differences in labor supply along the extensive margin in France vs. the US are driven by education and labor regulations or social norms regarding work among the young, retirement decisions for the old, and perhaps differences in family norms or policies regarding female market work, and not by the overall of taxes needed to fund the larger social state in France. Let us examine each in turn.

Youth labor. Child labor was prevalent before the rise of the social state and mass education (Basu 1999 provides a survey from a developing country perspective). It was common in most US states up until the Great Depression (Moehling 1999). US census data show that almost 20 percent of children aged 10 to 15 worked for pay at the end of the $19^{\text {th }}$ century and this declined in the early part of the $20^{\text {th }}$ century (US Census 1975 , series D80). Compulsory education mechanically reduces children labor supply. But labor regulations were also enacted to further reduce and eventually eradicate child labor (culminating in the Fair Labor Standards Act of 1938 for the US at the Federal level). Therefore, discouraging child labor has a strong social choice component over and above individual choices that families make for their children.

Old age labor. As we mentioned, work in old age was prevalent before the development of public retirement systems and dramatically decreases during the $20^{\text {th }}$ century when they are introduced. Panel A of Figure 5 depicts the fraction of elderly men aged 65 and

${ }^{15}$ This follows Blundell, Bozio, and Laroque (2013) who present such highly insightful graphs for the US, UK, and France at the annual level (instead of 5-year age bins). 
above working for pay in the US and France since the late $19^{\text {th }}$ century. In 1850-1880, almost 80 percent of US elderly men were still working, at a time when life expectancy at age 65 was only about half of what it is today (Blundell, French, and Tetlow 2017). The fraction working decreases starting in 1890 after civil war pensions are expanded (made available to any veteran no longer able to work due to old age or disability) and further shrinks after US social security payments start in the late 1930s. By 1930 the fraction of elderly working is only 25 percent. France follows a similar trend but starting from a lower level (54 percent working in 1895) and ending at an even lower level (5 percent working in 1980) after the retirement age falls dramatically in the post-World War II decades.

Trends in recent decades for the "young" elderly men aged 60 to 64 show the most dramatic shifts and are depicted on panel B using OECD data for France and the US, and also Germany which is a striking case study. Employment dramatic decreases in countries such as France and Germany up to 2000 followed up by an increase since then with US having a much flatter pattern. As documented by a large body of work (see Gruber and Wise 1999), these dramatic shifts are driven by changes in the pension systems and in particular retirement ages. Germany lowered the retirement age from 65 to 60 in 1973 and the fraction of men working at age 60-64 falls dramatically from 65 percent in 1973 down to 40 percent in the late 1970s. In the early 2000s, Germany increased the retirement age back to 65 and the fraction working reverts from 30 percent in 2002 to 67 percent in 2019 (as high as in the early 1970s). France considerably increased the generosity of public pensions through the 1980 s when age 60 was the retirement age norm. In the 1990 s, only 10 to 15 percent of the young elderly were working in France (down from over 50 percent in 1975). Since 2000, France has also reduced the generosity of pensions for the young elderly and the fraction working has increased (up to 34 percent in 2019) although not as dramatically as in Germany. The US much flatter pattern can be explained by the stability of retirement ages in the social security system.

Intriguingly, retirement programs also affect retirement age through social effects over and above traditional economic incentives: Seibold (2020) shows that German retirees are heavily influenced by statutory retirement ages even absent financial incentives. ${ }^{16}$

In sum, how much the elderly work is decided primarily through the social state by modulating the retirement programs.

Female market work. There has been a dramatic increase in female market work since mid-20 th century in advanced economies. Panel A in Figure 6 illustrates trends for the US, France, and the Netherlands (an interesting case study) since 1970 for males vs. females aged 25-54 (prime age). While prime age males have always worked at very high rates of around 90 percent, female market work used to be much lower than males but is only slightly lower than males today in these three countries. The timing and pace vary widely across countries. The US and France had relatively high female labor force participation in the 1970s (around 55 percent) but it was very low in the Netherlands (less

\footnotetext{
${ }^{16}$ The large effect created by the early retirement age (62 in the US) also shows that many people are unable to save to retire earlier but retire as soon as benefits become available, contradicting the standard rational life cycle model.
} 
than 25 percent in the early 1970s). Today, female employment rates are actually slightly higher in the Netherlands than in France or the US. Therefore, female labor force participation is greatly affected by social norms particularly around whether mothers should work outside the household, which end up codified in part through the social state in terms of family policies (such as publicly provided childcare and preschool, maternity labor regulations).

A striking and well-known historical example is illustrated on Panel B of Figure 6 that depicts the labor force participation of women (aged 16-64) in the United States from 1940 to 1965 . There was a temporary surge of almost 25 percent (or 10 points) exactly during World War II when additional labor was needed to support the war effort and fill in for men serving in the military. This was achieved through social mobilization coordinated by the government. The panel displays the most iconic poster of the era ("Rosie the Riveter") motivating women to work. The government was also able to organize childcare extremely fast so that young mothers could join the labor force as well. Mulligan (1998) notes that this extra labor supply was achieved in spite of much higher taxes needed to fund the war effort. As he concludes: "Is the wartime experience a success story for central planning?" It is certainly evidence of social labor supply choices.

Another striking example is given by single mothers in the US in the 1990s. Panel C of Figure 6 (reproduced from Kleven 2019) shows that the labor force participation rate of single mothers (aged 20-50) caught up with single women with no children in the 1990s during welfare reform that cut welfare support to non-working single parents and expanded the earned income tax credit (EITC) for working single parents. Therefore, a reform of the social state ended up having a dramatic labor supply effect. Economists have generally interpreted this as a labor supply response to the new incentives (see Grogger and Lynn 2005) but it can also be interpreted as a social choice: US society decided in the 1990s that single mothers should work and encoded this view through tax and transfer reforms. ${ }^{17}$

Intensive hours of work. The standard concern among economists is that the social state might discourage labor supply because of taxes and transfers. However, the social state also plays a direct active role in reducing hours of work by regulating overtime and imposing vacation mandates. Therefore, the concern of the social state seems instead to be that people might end up working too long hours with too little vacation time.

Historically, at the beginning of industrialization, there is indeed a concern that workers are working too many hours per week damaging their health, family life, and overall well-being. In the early $20^{\text {th }}$ century, organized labor fought for workday hourly limits and eventually the social state passed regulations. Fighting for hourly limits was considered as important as fighting for better wages (Roediger and Foner 1989).

To illustrate the role of work regulations, Figure 7 depicts average hours of work in the US and France among employees (pooling all employees regardless of age, gender, or part-time vs. full-time) from the OECD database since 1950. While hours of work in France were only slightly lower (7 percent) than the in the US in 1950 , they are now substantially lower (21 percent lower in 2019). Interestingly, expanded paid vacation

\footnotetext{
${ }^{17}$ As Kleven (2019) points out, other reforms such as EITC expansions took place at other times and had no visible effect in the time series depicted on the figure, suggesting that pure monetary incentives might not be the full explanation.
} 
time and hours of work regulations are associated with drops in hours of work in the French series. Mandated paid vacation time increased in 1968 (from 3 to 4 weeks) and in 1982 (to 5 weeks). Regular hours of work decreased from 40 to 39 in 1982 and down to 35 in 2000-2002 (Askenazy 2013). The drop in hours in 1968 and 1982 are especially visible. The US has always had a 40-hour week (since the New Deal) and no mandated paid vacation. Therefore, it is quite plausible that hours of work in France are lower because of more paid vacation time and more stringent hours of work regulations (see Alesina, Glaeser, and Sacerdote 2005 for a longer discussion along these lines).

Such regulations show that intensive labor supply choices are also partly a social choice. It is possible that vacation and hours regulation is a policy the French have chosen to reduce their hours of work because taxes are high, but this would still be a "social" labor supply response (engineered through government policy) as opposed to standard individual labor supply responses.

In sum, it appears that society has disutility of work for children, the elderly, and for very long hours or no vacation breaks, and regulates labor supply at the social level accordingly.

\section{Social Situations and Concerns for Inequality}

Although government is the most obvious social institution, many private institutions have social aspects where people take a group perspective instead of a purely individualistic perspective.

The household is the most basic example. It is modeled as a single unit that effectively acts as a super individual in most economic models. ${ }^{18}$ There are obviously individuals with different views within each household and hence potential conflicts but the "single unit" modeling is seen as a reasonable benchmark. ${ }^{19}$

A number of social institutions outside the family and aside from formal government also arise in various contexts and either pre-exist or supplement the social state. Villages in developing countries provide informal insurance (see e.g. Townsend 1994) not unlike the earlier hunter-gatherer societies we discussed above. Individuals are able to create common-pool resources to manage public goods outside of government as famously shown by Ostrom (1990) in many contexts across the world. People also form voluntary communes with strong egalitarian norms, the most famous and successful being the Israeli Kibbutz (Abramitzky 2018). These institutions manage to overcome the tragedy of the commons or the free-rider problem outside of the formal government.

The modern large employer is another example of a setting where cooperation takes place outside of market mechanisms as Coase (1937) famously theorized. Economists typically model firms as a hierarchical structure where employees work on behalf of owners. In some countries such as Germany or Finland, workers are represented on the board of large employers so that cooperation between workers and owners

\footnotetext{
${ }^{18}$ The unitary household is even extended to extremes such as the infinitely long living dynasty.

${ }^{19}$ The unitary household model has been challenged recognizing that power is not distributed equally among householders and matters for within household allocations (e.g. see Duflo 2003 for an empirical illustration in South Africa showing that pensions going to grandmothers benefit grandkids wellbeing more than pensions going to grandfathers).
} 
becomes less hierarchical. In practice, large and established employers absorb risk and offer steady work and compensation. They also fill gaps in the social state for example with retirement and health benefits in the United States. ${ }^{20}$ An extreme example of a social employer would be the modern university and its faculty workforce that receives tenure insurance and has a strong advisory voice on administrative matters.

Finally, nonprofit organizations are another type of social institutions. Individuals contribute voluntarily and the institutions serve an array of causes, and even create products that sometimes compete successfully with for-profit products with many modern examples (such as open source software). ${ }^{21}$

Therefore, social organization does seem to come naturally to us. We can easily take a group perspective and act accordingly.

\section{A. Cooperation and Surplus Distribution}

A group perspective requires cooperation, and this can naturally conflict with the individual perspective. How can then cooperation be sustained?

Cooperation benefits the group but faces two challenges: (1) how to overcome the classic social dilemma to achieve efficiency, (2) how to distribute the gains from cooperation which is an equity issue. Cooperation can be sustained in various ways. ${ }^{22}$ First, through altruism and reciprocity, individuals can take the group perspective as their own, e.g. individuals care about their family members in their household (see Sobel 2005 for a review). Second, cooperation can be achieved through authority where authority can arise from a hierarchy (e.g., an employer directing workers), social norms or rules. Third and related, there is resentment and punishment of non-cooperating individuals in settings where cooperation is expected. Resentment happens when altruism is not paid back with reciprocity (Fehr and Gachter 2000). Punishment can follow and particularly so when authority has been violated. Fourth, sustaining cooperation also requires a distribution of surplus that is acceptable to all parties. This last aspect is the key reason why we are so attuned to inequality.

Lab experiment evidence. The simplest evidence of cooperation in production and fairness in its subsequent distribution comes from a large body of lab experiment evidence.

\footnotetext{
${ }^{20}$ Indeed, there is a striking parallel between the rise of the coercive state and its latter transformation into a social state and the rise of industrial firms - initially harmful for the health of workers (Komlos 1998) - and their transformation into the modern large employer that offers "good jobs" with health and pension benefits. This transformation is still incomplete and possibly at risk of getting reversed as the power of organized labor wanes.

${ }^{21}$ Charitable giving is progressive on the contribution side with the rich contributing disproportionally (Fack and Landais 2016 compile US historical statistics) but cannot replace the state. For example, US aggregate charitable contributions (1.5 percent of national income) is less than 10 percent that tax revenue gap between France and US documented above.

${ }^{22}$ Game theory generally assumes individualistic preferences and tries to understand how cooperation can nonetheless be sustained in some context. But behavioral economics work has introduced preferences for fairness (e.g., Rabin 1993, Fehr and Schmidt 1999, Charness and Rabin 2002) or cooperation (e.g., Roemer 2019).
} 
Cooperation in production. The public good game is the most basic set-up of the social dilemma (see Leydard 1995 and Chauduri 2011 for surveys). Within a small group, each individual is given an endowment that she can divide between a public good or herself. The public good benefits all in the group so that the efficient solution is full public good contribution. But it is not a Nash equilibrium as playing selfish is always a dominant strategy. However, in practice, participants contribute significantly to the public good. Cooperation breaks down overtime in repeated games because cooperators get upset at free-riders, and actually are willing to spend resources to punish them (in variants of the game). Communication also helps sustain cooperation. This demonstrates the inclination of humans to cooperate and punish the selfish. There is also experimental work showing reciprocity in production. For example, Fehr, Kirchsteiger, Riedl (1993) show that recipients work harder for more generous employers even when hard work no longer affects compensation.

Distribution of surplus. The dictator game, where one player (the dictator) gets to split an endowment between herself and another player (the recipient), offers insights in the issue of distribution and the tension between social vs. individual motives (see Engel 2011 for a meta study of this large literature). The individualistic solution is to give away nothing yet about $2 / 3$ of dictators share with the recipient with equal splitting being the most common form of sharing. There is more sharing if the recipient helped create the endowment (and less if the dictator created it through her work) showing that how surplus is jointly produced matters a lot. There is also more sharing when the recipient is needy (consistent with social income support) and when the dictator is identified (social pressure). Non-student subjects give a lot more and so do people from small scale societies (closest to ancient hunter gatherer societies).

The ultimatum game is a refinement of the dictator game that allows the recipient to refuse offers they do not like in which case neither the dictator nor the recipient gets anything (see Thaler 1988 for an introduction and Roth 1995 and Guth and Kocher 2014 for surveys). Recipients reject offers that are too stingy and in turn proposers tend to share more with equal split being the most common sharing proposal. This shows that selfish dictators get punished even if punishment is costly to the recipient. And this in turn make dictators behave more socially with 50/50 splits being the safest choice that prevents any distribution conflict.

In summary, humans are willing to cooperate to achieve efficient outcomes and care about how surplus is distributed. This was shaped by our long evolution as a cooperative species but with individualistic tendencies that make the distribution of surplus a sensitive issue. Let us examine next why this is relevant to understand the modern economy.

\section{B. Joint Production and Pre-tax Distribution}

The standard economic model posits that wages are set competitively and hence equal to marginal product in equilibrium, which leaves no scope for a distributional conflict of pre-tax market incomes between workers and their employers. ${ }^{23}$ Yet, the distributional conflict between workers and owners has been very prominent historically and still is

${ }^{23}$ Economists have also studied non-competitive labor market models such as the monopsony (starting with Robinson 1969) but typically have focused on efficiency issues rather than equity. 
today. Production takes place within the firm through cooperation of workers and owners, where individual contributions are often hard to measure and where replacing workers or owners is costly. Contract theory has relaxed the assumption of perfect cooperation by introducing imperfect monitoring. Search and matching theory has introduced matching costs which creates a bilateral monopoly situation once a match has been made and there is surplus to be shared between the employer and the employee. Hence, a range of acceptable wages is possible, leaving room for distributional conflicts. Behavioral economics has introduced fairness and social preferences in the labor market (Akerlof 1982, Fehr, Goette, and Zehnder 2009) and contract theory (Fehr, Klein, and Schmidt 2007).

Rigid compensation rules. Using pay setting norms can help alleviate the distributional conflicts. Indeed, many employers and especially large ones use rigid compensation rules such as pay scales, across the board pay raises - such as cost-of-living adjustments or union bargained raises. ${ }^{24}$ There is evidence that workers are sensitive to their relative pay and dislike being paid less than their peers (see e.g., Card et al. 2012). As a result, there is often wage secrecy (Lawler 1965) and wage compression within firms (Akerlof and Yellen 1990).

Another consequence of the distributional conflict is that wages are downward rigid because pay cuts hurt morale and cooperation of workers (Bewley 1999). Recent empirical work has shown that wages are sticky to payroll taxes. With flexible wages, employee vs. employer side payroll taxes are economically equivalent theoretically but not so in practice because wages are rigid. If wages are rigid, employee side payroll tax changes fall on the employee while employer side changes fall on the employer (see e.g., Saez, Matsaganis, Tsakloglou 2012). ${ }^{25}$

There is also growing empirical evidence that better firms pay identically skilled workers better (see e.g., Card, Heining, and Kline 2013, Card, Cardoso, and Kline 2016) and that windfall to employers are shared with workers (see e.g., Kline et al. 2019, Saez, Seim, and Schoefer 2019).

Such rigid compensation rules extend beyond employers. For example, hedge fund managers get compensated with the $2 / 20$ rule ( 2 percent of the wealth managed plus 20 percent of the gains they make on behalf of client investors). Closer to home, academic authors generally split equally the credit for publications by listing authors in alphabetical order. To understand why splitting production is a delicate thing, just imagine yourself going through your publications and having to agree with co-authors on

\footnotetext{
${ }^{24}$ Pay increases are sometimes uniform in percent (and hence inequality neutral) but have been sometimes uniform in level (e.g. $\$ 1$ hourly wage increase for all) in which case they are strongly inequality reducing (see Pencavel 2020 for a US analysis in mid- $20^{\text {th }}$ century when union power was at its peak and Manacorda 2004 for the scala-mobile analysis in Italy).

${ }^{25}$ This rigidity due to distributional concerns is also visible in public policy and market pricing. It is well known that public policy reform is difficult because losers complain and mobilize against reform more intensely than winners, so that policies tend to be rigid. There is also upward rigidity in prices due to the distributional conflict between consumers and producers because unjustified price increases anger consumers (see Kahneman, Knetsch, and Thaler 1986 for a conceptual presentation and Blinder et al. 1998 for a detailed empirical analysis).
} 
the true split. This would of course be ripe for conflict generation. The nominal equal splitting norm saves us a lot of trouble.

In all these cases, the actual contribution does matter. Highly performing workers are more likely to get retained and promoted. Non-contributing co-authors may not be asked again to join a research project, etc. However, this quantity margin is not fast enough to systematically equate contribution and compensation, especially as economic conditions are constantly evolving.

Pre-tax redistribution. In contrast to public economists', the view of the US public is that inequality should be solved by private sector rather than government (see e.g., McCall 2013). The firm seems indeed a more directly obvious place of joint production than the nation as a whole, so pre-tax redistribution appears more natural than redistribution through taxes and transfers. Government remains a crucial but indirect player as it sets the rules of this distributional conflict: rules for organizing labor through unions, minimum wages, overtime pay, employment protection, safety in the workplace, etc.

To illustrate this, Figure 8 contrasts the popularity of pre-tax vs. tax redistribution by looking at US state level ballot initiatives for increasing the minimum wage vs. ballot initiatives to increase income taxes on upper incomes. The minimum wage is a form of pre-tax redistribution as it forces employers to increase pay of their lowest paid workers which must come at the expense of other workers, owners, or customers. Increasing the income tax on upper earners is naturally tax redistribution.

Voting behavior in state level ballot initiatives show overwhelming support for minimum wage increases. Since 1996, 25 out of 27 minimum wage initiatives were approved by voters. Support for minimum wage increases is equally strong in republican leaning vs. democratic leaning states. In contrast, initiatives to increase income taxes on upper earners have been much less successful with only 6 out of 23 passing since 1972 . Most well-known is the case of Massachusetts, a strongly Democratic leaning state, which tried and repeatedly failed to introduce progressivity in its state income tax.

Therefore, the ballot evidence is consistent with the view that pre-tax redistribution is more popular than tax redistribution. The extremely high tax rates that had existed in the United States from the 1930s up to 1980 were justified not as a form of revenue raising (tax redistribution) but instead as a form of check on very high pretax incomes. The extremely high top tax rates of the 1950s and 1960s never raised much revenue but effectively prevented excessive pay or the accumulation of great fortunes (Saez and Zucman 2019). ${ }^{26}$

\section{Conclusion}

This paper has argued that our social nature, absent from the standard economic model, is crucial to understand our large modern social states and why concerns about inequality are so pervasive. Taking care of the young, the sick, and the elderly has always

\footnotetext{
${ }^{26}$ Piketty, Saez, and Stantcheva (2014) show that, if higher top tax rates discourage top earners from bargaining for higher compensation, top tax rates in excess of the conventional revenue maximizing tax rate can be optimal.
} 
been done through families and communities and likely explains best why education, health care, and retirement benefits are carried out through the social state in today's advanced economies. Behavioral economics shows that we are not very good at solving these issues individually, but descriptive public economics shows that we are pretty good at solving them socially. What are the consequences of this discussion for positive and normative public economics?

Positive public economics. Social effects imply that standard preferences are only an incomplete description of individuals' economic behavior, and understanding social effects is important particularly on the labor supply dimension where such effects might be particularly large and relevant for public economics.

In particular, social effects can vary widely depending on situations and can also be shaped through policies. For example, female labor supply depends on society's view on the role of women but this can be changed quickly (such as during World War II in the US). This also implies that behavioral responses to taxes and transfers are not laws of nature but respond to the social context. For example, it is conceivable that the US welfare reform of the 1990s magnified the labor supply response of single mothers through social effects.

This makes empirical analysis more challenging as existing estimates might not have as much external validity as we thought. Economists have noted that "frictions"such as imperfect information or adjustment costs - can affect behavioral responses (see e.g. Chetty 2012 in the case of labor supply). But "frictions" is perhaps too narrow a concept as it does not capture the variety of social effects that can affect our economic behavior, and that future research might be able to map out.

Normative public economics. Because individuals are not always good at solving economic problems, revealed individual preferences may not be informative of social preferences. For example, if workers fail to save adequately for retirement on their own, this does not imply that society should let the elderly be in poverty. If people are impatient and heavily discount the future, this does not necessarily imply that society should as well and for example ignore the long-term costs of climate change.

Consequently, replacing social institutions by markets with individual choice might not always work well. Individual choice and markets work only when individuals' preferences (revealed through their behavior) line up with society's preferences.

Finally, a social system functions best when individuals internalize the social objective. For example, means-tested support for those in need works best if recipients do not try to game the system; a tax system works best if taxpayers do not systematically try to avoid and evade their tax obligations. Behavioral responses are not only costly in terms of public funds, but they can also undermine trust in the social program which is perhaps an even greater harm. Therefore, it is better to design the social system to try and eliminate behavioral elasticities rather than take existing behavioral elasticities as a given as public economists generally do. This opens up more possibilities for the design of public policies than economists generally recognize. 


\section{References:}

Abramitzky, Ran. 2018. The Mystery of the Kibbutz: Egalitarian Principles in a Capitalist World. Princeton, NJ: Princeton University Press.

Acemoglu, Daron, and James A. Robinson. 2012. Why Nations Fail: The Origins of Power, Prosperity, and Poverty. New York City, NY: Crown Publishing Group.

Akerlof, George. 1978. "The Economics of "Tagging" as Applied to the Optimal Income Tax, Welfare Programs, and Manpower Planning." American Economic Review 68(1): 819.

Akerlof, George. 1982. "Labor Contracts as Partial Gift Exchange.” Quarterly Journal of Economics 97, 543-569.

Akerlof, George A., and Robert J. Shiller. 2015. Phishing for Phools: The Economics of Manipulation and Deception. Princeton, NJ: Princeton University Press.

Akerlof, George A., and Janet L. Yellen. 1990. "The Fair Wage-Effort Hypothesis and Unemployment." Quarterly Journal of Economics 105(2): 255-283.

Alesina, Alberto and Edward Glaeser. 2004. Fighting Poverty in the US and Europe: A World of Difference. Oxford: Oxford University Press.

Alesina, Alberto, Edward Glaeser, and Bruce Sacerdote. 2005. "Work and Leisure in the United States and Europe: Why so Different?" NBER Macroeconomics Annual 20: 1-64.

Alesina, Alberto, and Eliana La Ferrara. 2005. "Ethnic Diversity and Economic Performance." Journal of Economic Literature 43(3): 762-800.

Alesina, Alberto, Armando Miano, and Stefanie Stantcheva. 2018. "Immigration and Redistribution.” National Bureau of Economic Research Working Paper No. 24733.

Alvaredo, Facundo, Lucas Chancel, Thomas Piketty, Emmanuel Saez, and Gabriel Zucman. 2018. World Inequality Report 2018. Cambridge, MA: Harvard University Press.

Ardant, Gabriel. 1971. Histoire de l'Impot (Volumes 1 and 2), Paris: Fayard.

Askenazy, Philippe. 2013. "Working Time Regulation in France from 1996 to 2012." Cambridge Journal of Economics 37(2): 323-347.

Basu, Kaushik. 1999. "Child Labor: Cause, Consequence, and Cure, with Remarks on International Labor Standards.” Journal of Economic Literature 37(3): 1083-1119. 
Baum, Sandy. 2016. Student debt: Rhetoric and Realities of Higher Education Financing. New York City, NY: Springer.

Bewley, Truman F. 2009. Why Wages Don't Fall During a Recession. Cambridge, MA: Harvard University Press.

Biesele, Megan, and Nancy Howell. 1981. "“The Old People Give You Life": Aging among !Kung Hunter-Gatherers." In Pamela T. Amoss and Stevan Harrell, editors, Other Ways of Growing Old: Anthropological Perspectives. Stanford, CA: Stanford University Press.

Blau, Francine and Lawrence Kahn. 2007. "Changes in the Labor Supply Behavior of Married Women: 1980-2000.” Journal of Labor Economics 25(3): 393-438.

Blinder, Alan S., Elie R.D. Canetti, David E. Lebow, and Jeremy B. Rudd. 1998. Asking about Prices. New York City, NY: Russell Sage Foundation.

Blundell, Richard, Antoine Bozio, and Guy Laroque. 2013. "Extensive and Intensive Margins of Labour Supply: Work and Working Hours in the US, the UK and France." Fiscal Studies 34(1): 1-29.

Blundell, Richard, Eric French, and Gemma Tetlow. 2017 "Retirement Incentives and Labor Supply." In John Piggott and Alan Woodland eds., Handbook of Population Aging, Amsterdam: North Holland.

Blundell, Richard and Thomas MaCurdy. 1999. "Labor Supply: A Review of Alternative Approaches." In O. Ashenfelter, D. Card, eds., Handbook of Labor Economics, Amsterdam: North-Holland, volume 3.

Boehm, Christopher. 1999. Hierarchy in the Forest: The Evolution of Egalitarian Behavior. Cambridge, MA: Harvard University Press.

Bozio, Antoine, Bertrand Garbinti, Jonathan Goupille-Lebret, Malka Guillot, and Thomas Piketty. 2020. "Predistribution vs. Redistribution: Evidence from France and the U.S.", CEPR Discussion Paper 15415.

Brown, Jeffrey, Julia Lynn Coronado, and Don Fullerton. 2009. "Is Social Security Part of the Social Safety Net?" Tax policy and the Economy 23: 37-72.

Card, David, Ana Rute Cardoso, and Patrick Kline. 2016 "Bargaining, Sorting, and the Gender Wage Gap: Quantifying the Impact of Firms on the Relative Pay of Women." Quarterly Journal of Economics 131, 633-686.

Card, David, Jorg Heining, and Patrick Kline. 2013 "Workplace Heterogeneity and the Rise of West German Wage Inequality," Quarterly Journal of Economics 128, 967-1015. 
Card, David, Alexandre Mas, Enrico Moretti, and Emmanuel Saez. 2012. "Inequality at Work: The Effect of Peer Salaries on Job Satisfaction." American Economic Review 102(6): 2981-3003.

Case, Anne, and Angus Deaton. 2020. Deaths of Despair and the Future of Capitalism. Princeton, NJ: Princeton University Press.

Caspari, Rachel, and Sang-Hee Lee. 2004. "Older Age Becomes Common Late in Human Evolution." Proceedings of the National Academy of Sciences 101(30): 10895-10900.

Chandra, Amitabh, Benjamin Handel, and Joshua Schwartzstein. 2019. "Behavioral Economics and Health-Care Markets." In Handbook of Behavioral Economics: Applications and Foundations 1, vol. 2, 459-502. Amsterdam: North-Holland.

Charness, Gary and Matthew Rabin. 2002. "Understanding Social Preferences with Simple Tests." Quarterly Journal of Economics 117, 817-869.

Chaudhuri, Ananish. 2011. "Sustaining Cooperation in Laboratory Public Goods Experiments: A Selective Survey of the Literature." Experimental economics 14(1): 4783.

Chetty, Raj. 2012. "Bounds on Elasticities with Optimization Frictions: A Synthesis of Micro and Macro Evidence on Labor Supply.” Econometrica 80(3): 969-1018.

Coase, Ronald H. 1937. "The Nature of the Firm.” Economica 4(16): 386-405.

Costa, Dora L., 1998. "The Evolution of Retirement." In: Costa, D. L. (Ed.), The Evolution of Retirement: An American Economic History, 1880-1990. University of Chicago Press.

Deming, David J., Claudia Goldin, and Lawrence F. Katz. 2012. "The For-profit Postsecondary School Sector: Nimble Critters or Agile Predators?” Journal of Economic Perspectives 26(1): 139-64.

Diamond, Jared. 1997. Guns, Germs and Steel: A Short History of Everybody for the Last 13,000 Years. New York City, NY: W.W. Norton.

Duflo, Esther. 2001. "Schooling and Labor Market Consequences of School Construction in Indonesia: Evidence from an Unusual Policy Experiment." American Economic Review 91(4): 795-813.

Duflo, Esther. 2003. "Grandmothers and Granddaughters: Old-Age Pensions and Intrahousehold Allocation in South Africa." World Bank Economic Review 17(1): 1-25.

Easterlin, Richard A. 1981. "Why Isn't the Whole World Developed?" Journal of Economic History 41(1): 1-17. 
Eaton, Charlie, Sabrina T. Howell, and Constantine Yannelis. 2020. "When Investor Incentives and Consumer Interests Diverge: Private Equity in Higher Education." Review of Financial Studies 33(9): 4024-4060.

Edgeworth, Francis Y. 1897. "The Pure Theory of Taxation.” Economic Journal 7(25): 46-70.

Einhorn, Robin L. 2008. American Taxation, American Slavery. Chicago, IL: University of Chicago Press.

Engel, Christoph. 2011. "Dictator Games: A Meta Study." Experimental Economics 14(4): 583-610.

Fack, Gabrielle, and Camille Landais, eds. 2016. Charitable Giving and Tax Policy: A Historical and Comparative Perspective. Oxford: Oxford University Press.

Fehr, Ernst and Simon Gachter. 2000. "Fairness and Retaliation: The Economics of Reciprocity." Journal of Economic Perspectives 14(3), 159-181.

Fehr, Ernst, Lorenz Goette, and Christian Zehnder. 2009. "A Behavioral Account of the Labor Market: The Role of Fairness Concerns." Annual Review of Economics 1, 355384.

Fehr, Ernst, Georg Kirchsteiger, and Arno Riedl. 1993. "Does Fairness Prevent Market Clearing? An Experimental Investigation." Quarterly Journal of Economics 108(2): 437459.

Fehr, Ernst and Klaus M. Schmidt. 1999. "A Theory of Fairness, Competition, and Cooperation." Quarterly Journal of Economics 114, 817-868.

Firth, Raymond. 1939. Primitive Polynesian Economy. London: George Routledge and Sons.

Flora, Peter. 1983. State, Economy, and Society in Western Europe, 1815-1975, Vol. 1. London: Macmillan Press.

Gintis, Herbert, Samuel Bowles, Robert Boyd, and Ernst Fehr. 2003. "Explaining Altruistic Behavior in Humans." Evolution and Human Behavior 24(3): 153-172.

Grogger, Jeffrey and Lynn Karoly. 2005. Welfare Reform: Effects of a Decade of Change. Cambridge, MA: Harvard University Press.

Gruber, Jonathan. 2016. Public Finance and Public Policy. Fourth edition. Macmillan. 
Gruber, Jonathan, and David A. Wise, eds. 1999. Social Security and Retirement around the World. Chicago, IL: University of Chicago Press.

Güth, Werner, and Martin G. Kocher. 2014. "More than Thirty Years of Ultimatum Bargaining Experiments: Motives, Variations, and a Survey of the Recent Literature." Journal of Economic Behavior \& Organization 108: 396-409.

Harari, Yuval Noah. 2014. Sapiens: A Brief History of Humankind. New York City, NY: Random House.

Henrich, Joseph Patrick, Robert Boyd, Samuel Bowles, Ernst Fehr, Colin Camerer, and Herbert Gintis, eds. 2004. Foundations of Human Sociality: Economic Experiments and Ethnographic Evidence from Fifteen Small-Scale Societies. Oxford: Oxford University Press.

Hvidberg, Kristoffer B., Claus Kreiner, and Stefanie Stantcheva. 2020. "Social Position and Fairness Views.” National Bureau of Economic Research Working No. 28099.

Kahneman, Daniel, Jack L. Knetsch, and Richard Thaler. 1986. "Fairness as a Constraint on Profit Seeking: Entitlements in the Market." American Economic Review 76(4), 72841.

Kleven, Henrik. 2019. "The EITC and the Extensive Margin: A Reappraisal." NBER Working Paper No. 26405.

Kline, Patrick, Neviana Petkova, Heidi Williams, and Owen Zidar. 2019. "Who Profits from Patents? Rent-Sharing at Innovative Firms." Quarterly Journal of Economics 134(3): 1343-1404.

Komlos, John. 1998. "Shrinking in a Growing Economy? The Mystery of Physical Stature during the Industrial Revolution.” Journal of Economic History 58(3): 779-802.

Laibson, David. 2018. "Private Paternalism, the Commitment Puzzle, and Model-Free Equilibrium.” AEA Papers and Proceedings 108: 1-21.

Lawler, Edward E. 1965. "Managers' Perceptions of Their Subordinates' Pay and of Their Superiors' Pay." Personnel Psychology 18 (4): 413-22.

Lee, Jong-Wha, and Hanol Lee. 2016. "Human Capital in the Long Run." Journal of Development Economics 122: 147-169.

Ledyard, O. 1995. "Public Goods: Some Experimental Results.” In J. Kagel \& A. Roth (Eds.), Handbook of Experimental Economics. Princeton: Princeton University Press (Chap. 2). 
Lindert, Peter H. 2004. Growing Public. Volumes 1 and 2. Cambridge: Cambridge University Press.

Lucas, Robert E. 2004. "The Industrial Revolution: Past and Future." 2003 Annual Report Essay, Federal Reserve Bank of Minneapolis.

Luttmer, Erzo FP. 2005. "Neighbors as Negatives: Relative Earnings and Well-Being." Quarterly Journal of Economics 120(3): 963-1002.

Maddison, Angus. 2007. The World Economy. Volume 1: A Millennial Perspective. Volume 2: Historical statistics. Academic Foundation.

Madrian, Brigitte and Dennis Shea. 2001. "The Power of Suggestion: Inertia in 401 (k) Participation and Savings Behavior." Quarterly Journal of Economics 116(4): 11491187.

Malinowski, Bronislaw, 1922. Argonauts of the Western Pacific: An account of Native Enterprise and Adventure in the Archipelagoes of Melanesian New Guinea. New York City, NY: Routledge.

Manacorda, Marco. 2004. "Can the Scala Mobile Explain the Fall and Rise of Earnings Inequality in Italy? A Semiparametric Analysis, 1977-1993." Journal of Labor Economics 22(3): 585-613.

Marchand, Olivier and Claude Thélot. 1991. Deux Siècles de Travail en France. Paris: INSEE.

Mauss, Marcel. 1954. The Gift: The Form and Reason for Exchange in Archaic Societies. New York: Routledge (first published in French in 1925).

McCall, Leslie. 2013. The Undeserving Rich: American Beliefs about Inequality, Opportunity, and Redistribution. Cambridge: Cambridge University Press.

Meyer, Bruce and Dan Rosenbaum. 2001. "Welfare, the Earned Income Tax Credit, and the Labor Supply of Single Mothers." Quarterly Journal of Economics 116(3): 10631114.

Meyer, John W., Francisco O. Ramirez, and Yasemin Nuhoḡlu Soysal. 1992. "World Expansion of Mass Education, 1870-1980." Sociology of Education 65(2): 128-149.

Minois, Georges. 1989. History of Old Age: From Antiquity to the Renaissance. Chicago: University of Chicago Press (first published in 1954).

Moehling, Carolyn. 1999. "State Child Labor Laws and the Decline of Child Labor." Explorations in Economic History 36(1): 72-106. 
Mirrlees, James A. 1971. "An Exploration in the Theory of Optimum Income Taxation." Review of Economic Studies 38(2): 175-208.

Mulligan, Casey B. 1998. "Pecuniary Incentives to Work in the United States during World War II.” Journal of Political Economy 106(5): 1033-1077.

National Center for Education Statistics. 2020. Digest of Education Statistics. Online at https://nces.ed.gov/programs/digest/

Organisation for Economic Cooperation and Development (OECD). 2020a. Revenue Statistics, 1965-2019. Paris: OECD Press.

Organisation for Economic Cooperation and Development (OECD). 2020b. Education Spending. Paris: OECD Press. Online at https://data.oecd.org/eduresource/educationspending.htm

Organisation for Economic Cooperation and Development (OECD). 2020c. Health Statistics. Paris: OECD Press. Online at http://www.oecd.org/els/health-systems/healthdata.htm

Ostrom, Elinor. 1990. Governing the Commons: The Evolution of Institutions for Collective Action. Cambridge: Cambridge University Press.

Pencavel, John. 1986. "Labor Supply of Men: A Survey." In O. Ashenfelter and R. Layard (eds.) Handbook of Labor Economics, Volume 1. Amsterdam: Elsevier-North Holland.

Pencavel, John. 2020. "Wage Differentials, Bargaining Protocols, and Trade Unionism in Mid-Twentieth-Century American Labor Markets.” Forthcoming ILR Review.

Pew Research Center. 2019. "Little Public Support for Reductions in Federal Spending." April 11.

Piketty, Thomas. 2014. Capital in the $21^{\text {st }}$ Century. Cambridge, MA: Harvard University Press.

Piketty, Thomas. 2020. Capital and Ideology. Cambridge, MA: Harvard University Press.

Piketty, Thomas and Emmanuel Saez. 2013. "Optimal Labor Income Taxation." Chapter 7, in A. Auerbach, R. Chetty, M. Feldstein, and E. Saez (eds.) Handbook of Public Economics, Volume 5. Amsterdam: Elsevier-North Holland.

Piketty, Thomas, Emmanuel Saez, and Stefanie Stantcheva. 2014. "Optimal Taxation of Top Labor Incomes: A Tale of Three Elasticities." American Economic Journal: Economic Policy 6(1): 230-71. 
Piketty, Thomas, Emmanuel Saez, and Gabriel Zucman. 2018. "Distributional National Accounts: Methods and Estimates for the United States." Quarterly Journal of Economics 133(2): 553-609.

Piketty, Thomas, and Gabriel Zucman. 2014. "Capital is Back: Wealth-Income Ratios in Rich Countries 1700-2010.” Quarterly Journal of Economics 129(3), 1255-1310.

Polanyi, Karl. 1944. The Great Transformation. Boston, MA: Beacon press.

Rabin, Matthew. 1993. "Incorporating Fairness into Game Theory and Economics." American Economic Review 83(5), 1281-1302.

Rawls, John. 1971. A Theory of Justice. Cambridge, MA: Harvard University Press.

Robinson, Joan. 1969. The Economics of Imperfect Competition. New York City, NY: Springer.

Roediger, David R., and Philip Sheldon Foner. 1989. Our Own Time: A History of American Labor and the Working Day. New York City, NY: Verso.

Roemer, John. 2019. How We Cooperate: A Theory of Kantian Optimization. New Haven, CT: Yale University Press.

Saez, Emmanuel, Manos Matsaganis, and Panos Tsakloglou. 2012. "Earnings Determination and Taxes: Evidence from a Cohort-Based Payroll Tax Reform in Greece." Quarterly Journal of Economics 127 (1): 493-533.

Saez, Emmanuel, Benjamin Schoefer, and David Seim. 2019. "Payroll Taxes, Firm Behavior, and Rent Sharing: Evidence from a Young Workers' Tax Cut in Sweden." American Economic Review 109(5): 1717-1763.

Saez, Emmanuel, and Stefanie Stantcheva. "Generalized Social Marginal Welfare Weights for Optimal Tax Theory." American Economic Review 106(1): 24-45.

Saez, Emmanuel, and Gabriel Zucman. 2019. The Triumph of Injustice: How the Rich Dodge Taxes and How to Make Them Pay. New York City, NY: WW Norton \& Company.

Sahlins, Marshall. 1972. Stone Age Economics. New York City, NY: Taylor \& Francis.

Scott, James C. 2017. Against the Grain: A Deep History of the Earliest States. New Heaven, CT: Yale University Press.

Seibold, Arthur. 2020. "Reference Points for Retirement Behavior: Evidence from German Pension Discontinuities." Forthcoming American Economic Review. 
Sobel, Joel. 2005. "Interdependent Preferences and Reciprocity." Journal of Economic Literature 43, 392-436.

Stantcheva, Stefanie. 2020. “Understanding Tax Policy: How do People Reason?” NBER Working Paper 27699.

Stanley, Marcus. 2003. "College Education and the Midcentury GI Bills." Quarterly Journal of Economics 118(2): 671-708.

Tattersall, Ian. 2012. Masters of the Planet: The Search for our Human Origins. New York City, NY: St. Martin's Press.

Thaler, Richard H. 1988. "Anomalies: The Ultimatum Game." Journal of Economic Perspectives 2(4): 195-206.

Thaler, Richard H. 2015. Misbehaving: The Making of Behavioral Economics. New York: W. W. Norton.

Thaler, Richard H., and Cass R. Sunstein. 2009. Nudge: Improving Decisions about Health, Wealth, and Happiness. Londong: Penguin Books.

Thatcher, Margaret. 1987. 'Interview for "Woman's Own" ("No Such Thing as Society").' in Margaret Thatcher Foundation: Speeches, Interviews and Other Statements. London.

Thurnwald, Richard. 2018. Economics in Primitive Communities. New York: Routledge (first published in 1932).

Townsend, Robert M. 1994. "Risk and Insurance in Village India." Econometrica 62(3): $539-591$.

US Department of Commerce, Bureau of Census. 1975. Historical Statistics of the United States: Colonial Times to 1970. Washington, DC: US Government Printing Press.

Van Horn Melton, James. 1988. Absolutism and the Eighteenth-century Origins of Compulsory Schooling in Prussia and Austria. Cambridge: Cambridge University Press.

Webber, Carolyn, and Aaron B. Wildavsky. 1986. A History of Taxation and Expenditure in the Western World. New York City, NY: Simon and Schuster.

Wilk, Richard R., and Lisa Cliggett. 2007. Economies and Cultures: Foundations of Economic Anthropology. Second Edition. Boulder, CO: Westview Press.

Williams, George C. 1957. "Pleiotropy, Natural Selection, and the Evolution of Senescence." Evolution 11(4): 398-411. 
Wilson, Edward O. 2012. The Social Conquest of Earth. New York City, NY: WW Norton.

Woodburn, James. 1982. "Egalitarian Societies.” Man, New Series 17(3): 431-451.

World Inequality Lab. 2020. "Distributional National Accounts Guidelines Methods and Concepts Used in the World Inequality Database". Online at wid.world. 
Panel A. Top 10\% income shares in the US and France, 1910-2018

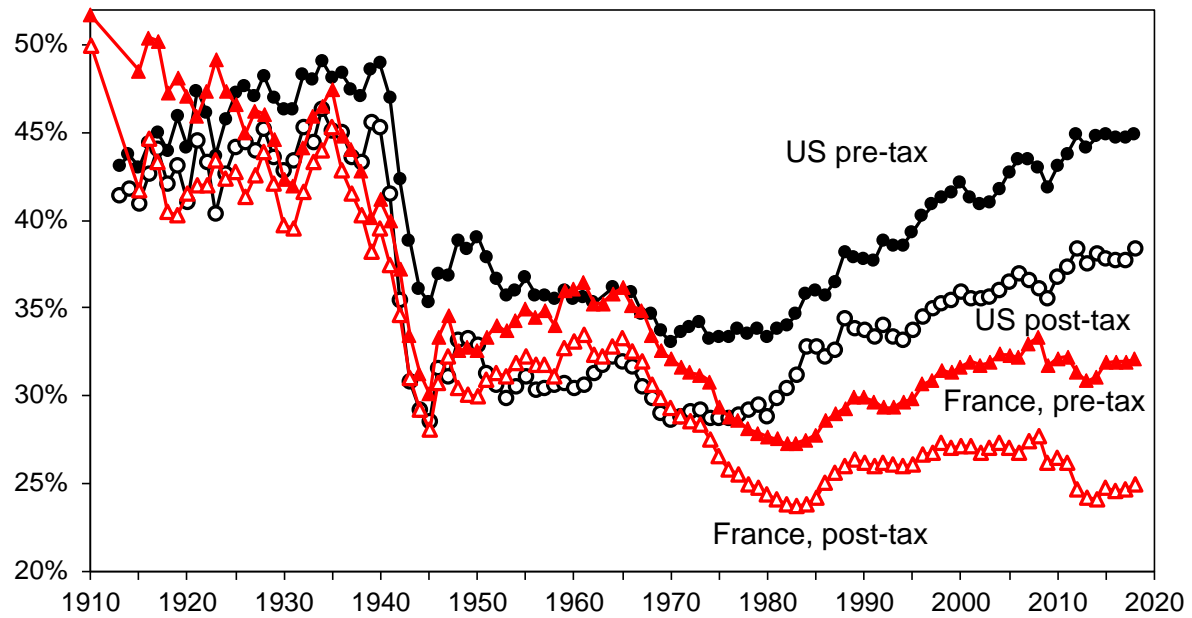

Panel B. Average tax rates by income group in 2018: US vs. France

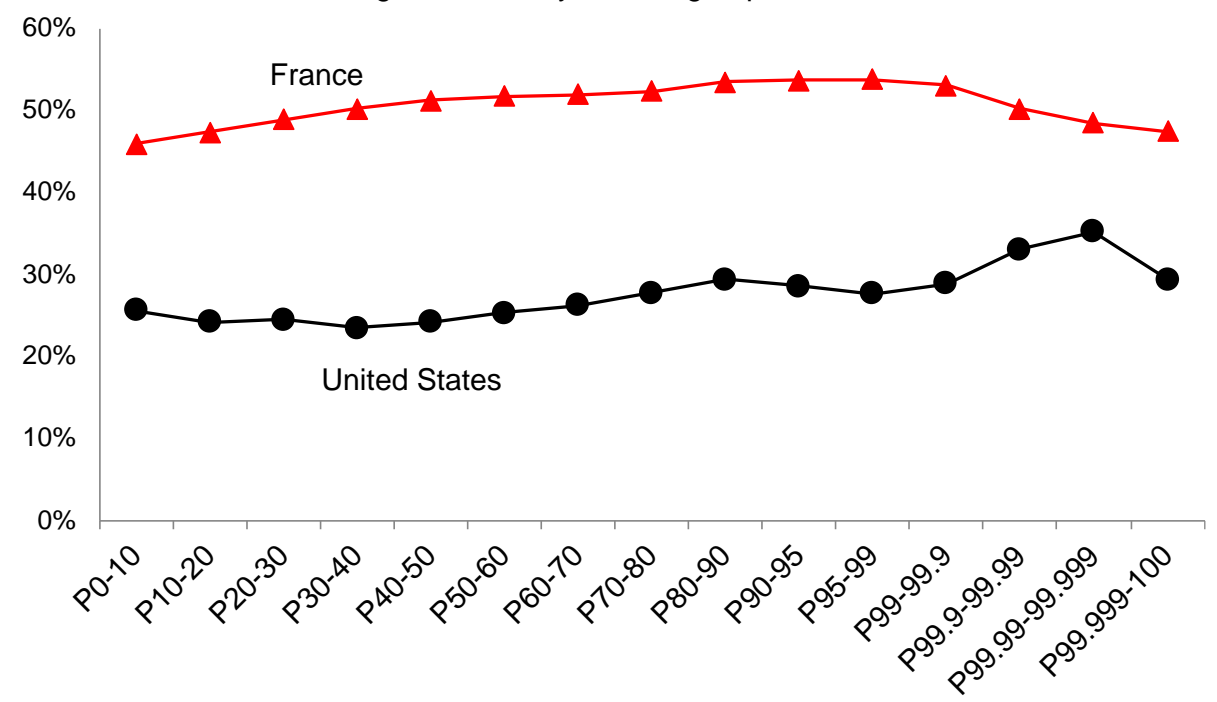

Figure 1: Inequality and Government

This figure illustrates the evolution of inequality and the direct impact of government through taxes and transfers in the United States and France. Panel A depicts the share of total national income earned by the top 10 percent of adults (aged 20 and above) from 1910 to 2018 on a pre-tax basis and post-tax basis. Income within married couples is equally split. Pre-tax income is before taxes and excluding government transfers. Post-tax income is after subtracting all taxes and including all government transfers and spending. Panel B depicts the average tax rate (as a percent of pre-tax income) in 2018 by decile (P0-10 is the bottom decile, etc.) with smaller breakdown within the top decile. It includes taxes at all levels of government. Series for both countries follow the same distributional national account methodology (World Inequality Lab 2020).

Source: Piketty, Saez, and Zucman (2018), September 2020 update for the United States. Bozio et al. (2020) for France. 
Panel A. The rise of the fiscal state
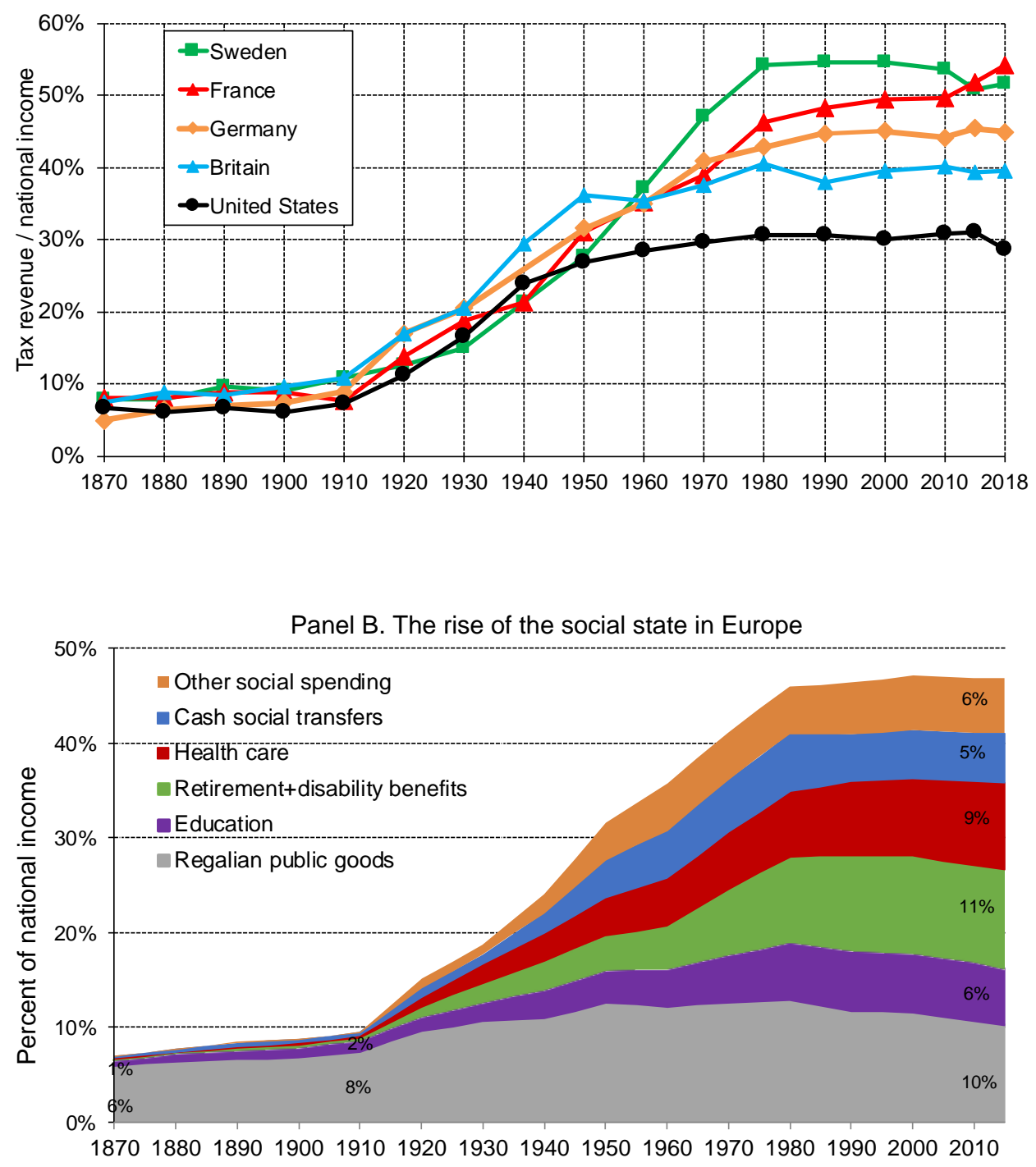

Figure 2: The Rise of Government in the $20^{\text {th }}$ Century

Panel A depicts total tax revenue as a percent of national income by decade in five countries. Taxes at all levels of government are included. This is reproduced from Piketty (2020, Figure 10.14) and updating the last point to 2018. Panel B depicts the composition of government spending by decade in Europe (average for Germany, France, Britain and Sweden). This is reproduced from Piketty (2020, Figure 10.15). Regalian public goods includes defense, law and order, administration, infrastructure. Cash social transfers include unemployment benefits, family benefits, and means-tested benefits. Other social spending includes in-kind spending such as public housing.

Source: Piketty (2020, Figures 10.14 and 10.15) created from OECD statistics and earlier historical statistics. 
Panel A. School enrollment at ages 5-14, 1830-1930

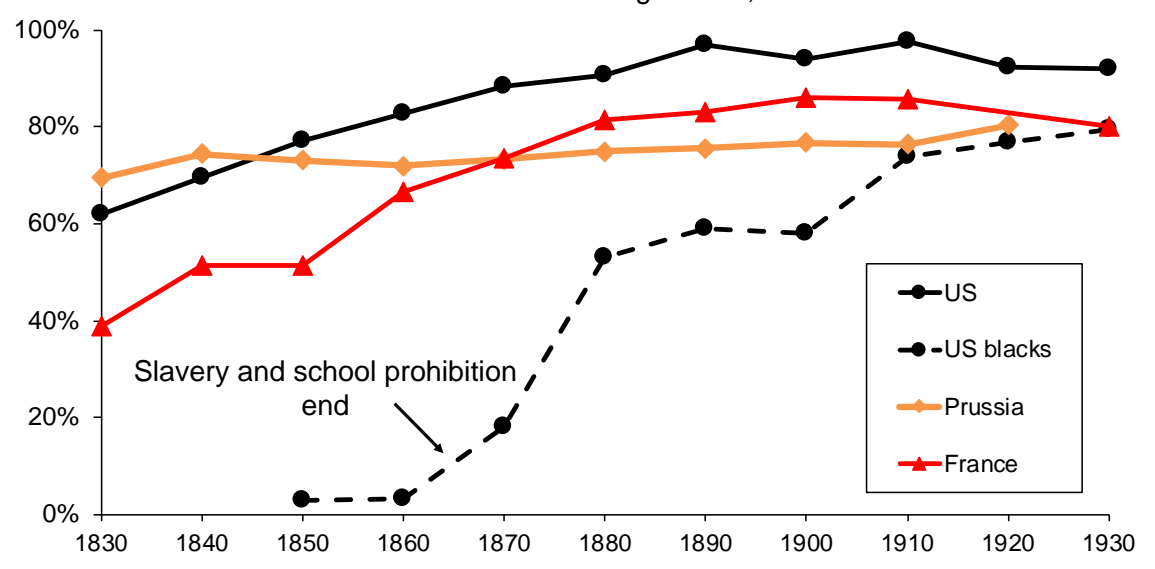

Panel B. Primary school enrollment in Russia, Korea and Indonesia

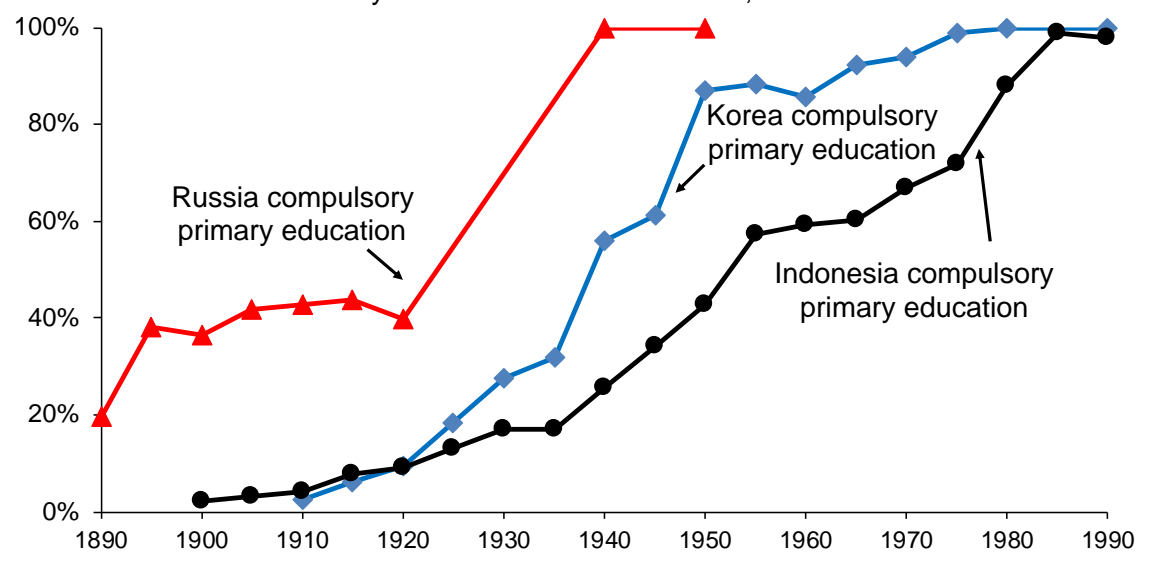

Figure 3: The Rise of Mass Education

Panel A depicts the fraction of children aged 5-14 enrolled in school (public or private) in the United States, among Blacks in the US, in Prussia, and France from 1830 to 1930. Enslaved children in America were prohibited from attending schools. Panel B depicts the fraction of children enrolled in primary school (public or private) in Russia, Korea, and Indonesia from 1890 to 1990 and flags when compulsory primary education was introduced in each country. In each of these three countries, compulsory schooling leads to a large increase in primary school enrollment in the following years.

Source: Panel A: Lindert (2004) and US Census Bureau (1975, series H435). Panel B: Lee and Lee (2016). 
Panel A. Employment rates of men by age, 2019

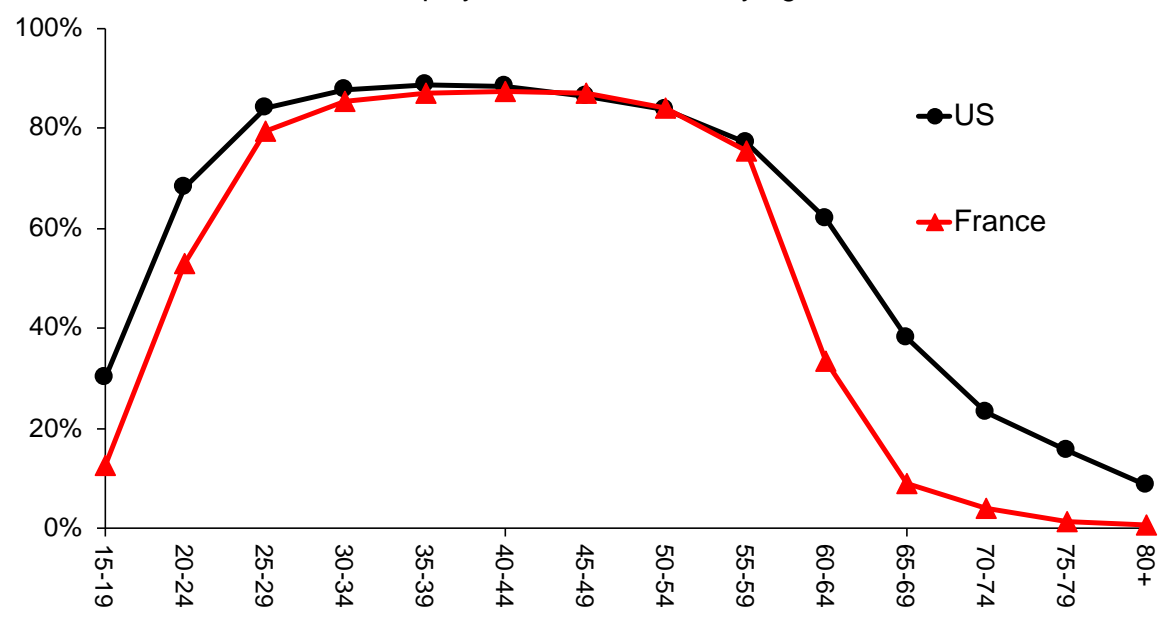

Panel B. Employment rates of women by age, 2019

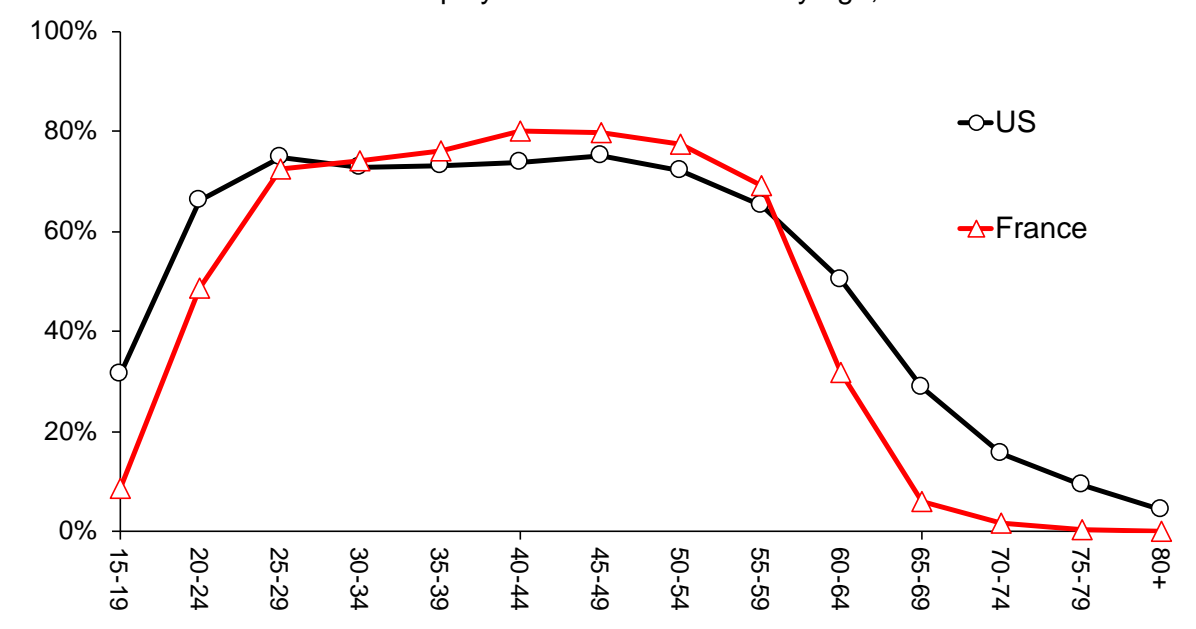

Figure 4: Employment Rates by Age in France vs. the US

This figure depicts the employment rate (people working divided by population) by 5-year age bins in the United States and France in 2019. Employment rates are similar in both countries in prime age (25-59) but smaller among the young and especially the old in France.

Source: OECD statistics online at stats.oecd.org 
Panel A. Employment rates of men aged 65+, 1850-1980

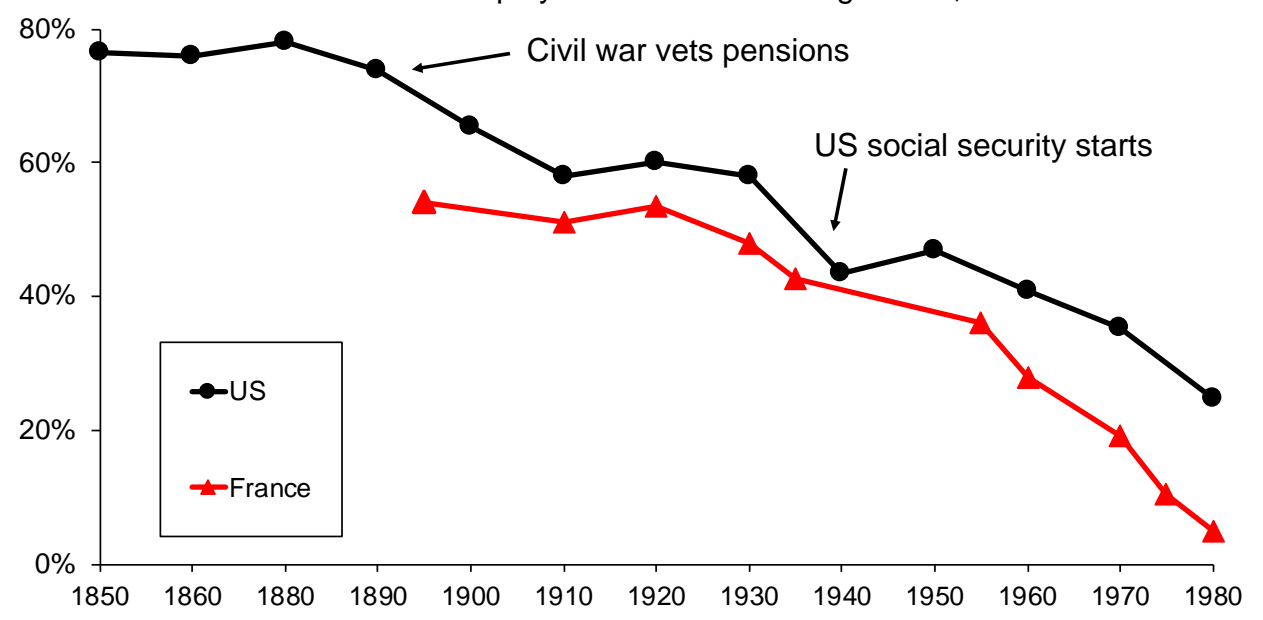

Panel B. Employment rates of men aged 60-64, 1970-2019

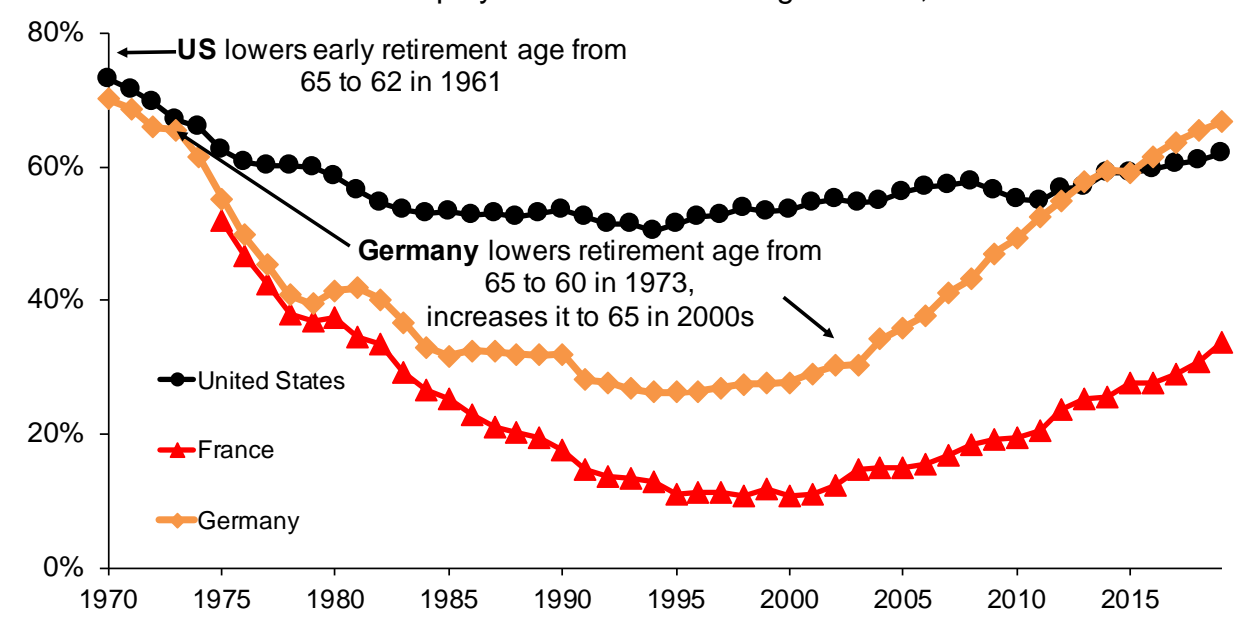

Figure 5: Old Age Employment and Retirement Systems

This figure depicts the employment rate (people working divided by population) among those aged 65 and above in the US and France from 1850 to 1980 (Panel A) and among those aged 60-64 in the US, France, and Germany since 1970 (Panel B). The employment rate of the elderly is tightly connected to the development of public retirement systems.

Source: Panel A, United States from Census data presented by Costa (1998, Table 2.A.2), France from Marchand and Thélot (1991). Panel B, OECD statistics online at stats.oecd.org 

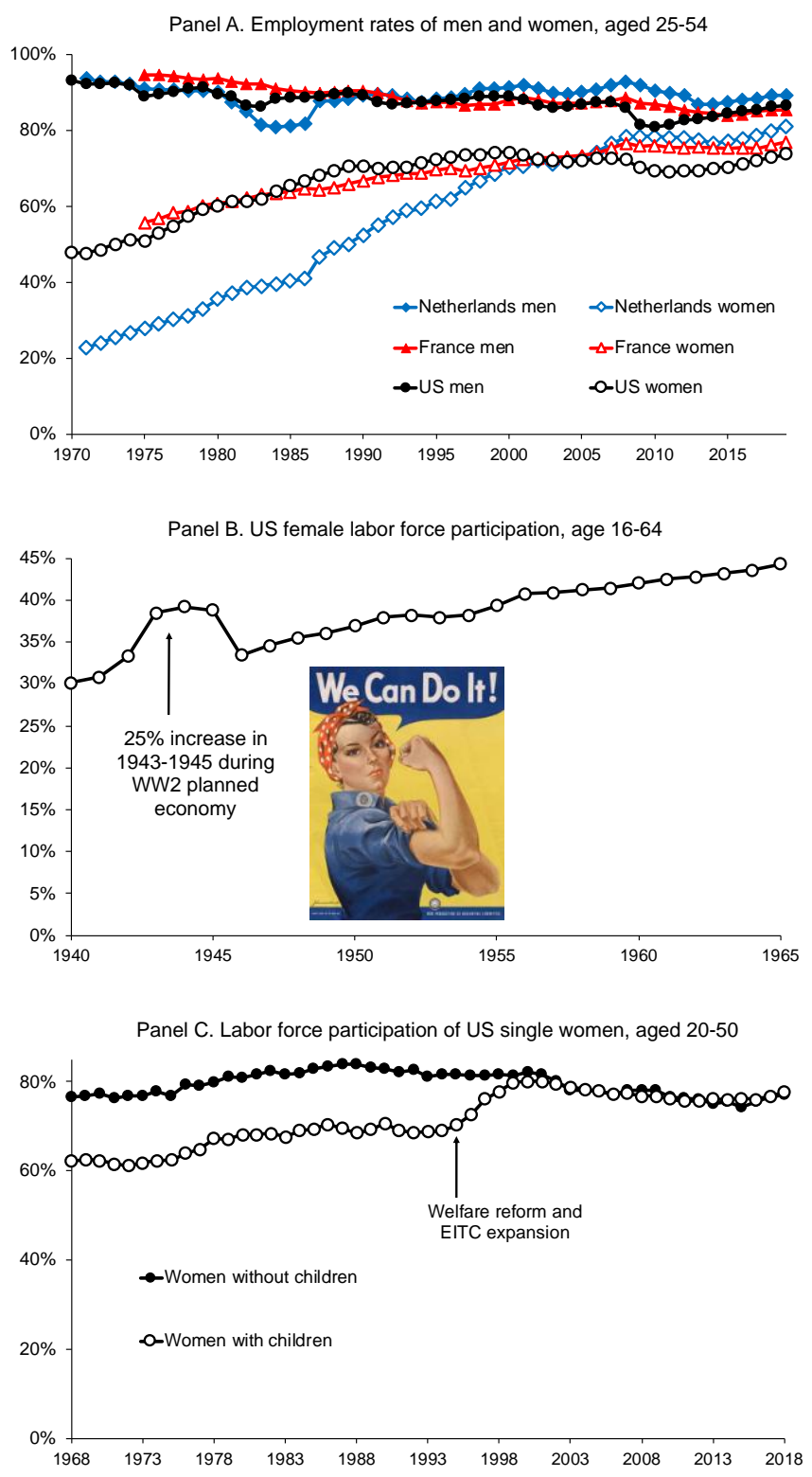

\section{Figure 6: Social Effects in Female Market Employment}

Panel A depicts the employment rates of prime age (age 25-54) men and women in the United States, France, and the Netherlands since 1970. While male market employment has been high and stable, female market employment rate has steadily increased due to changing norms regarding female employment (the Netherlands being an extreme case). Panel B depicts the labor force participation of women (aged 16-64) in the United States from 1940 to 1965. There was a temporary surge during World War II achieved through social mobilization (the most iconic poster is reproduced on the graph). Panel C compares the labor force participation of single women aged 20-50 with children and without children from 1968 to 2018. Both series are very parallel but catch up permanently in just 5 years from 1994 to 1999 during welfare reform and the EITC expansion.

Source: Panel A, OECD statistics online at stats.oecd.org. Panel B, US Census Bureau (1975, series D3641 estimated using Current Population Report survey data). Panel C reproduces Figure 3 from Kleven (2019) estimated using Current Population Survey data. 


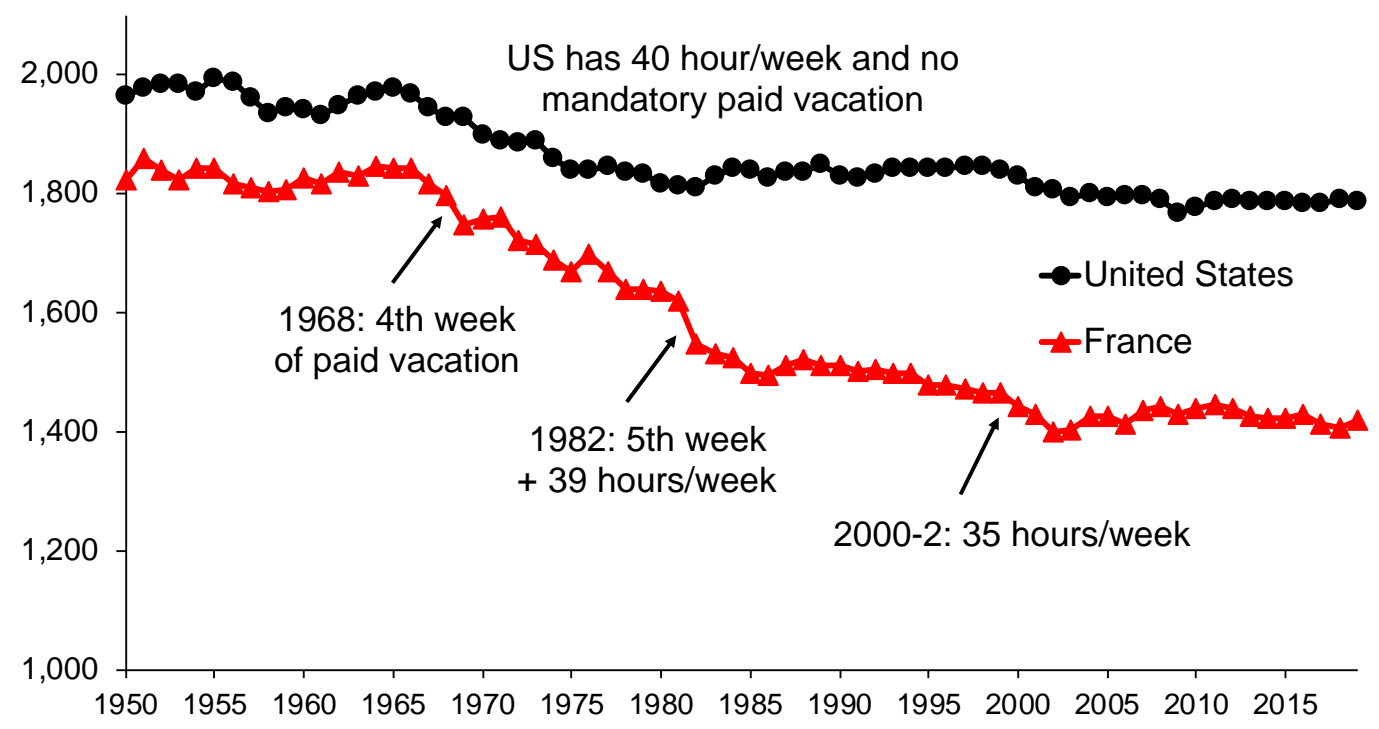

Figure 7: Average Annual Hours of Work of Employees

The figure depicts the average annual hours of work of employees in the United States and France since 1950. The sample includes all employed workers (any age or gender, part-time and full-time). Hours of work are actual hours (including any overtime). Hours of work in France have trended down relative to the US with visible steps when paid vacation is expanded $\left(4^{\text {th }}\right.$ week in $1968,5^{\text {th }}$ week in 1982$)$ and normal weekly hours of work are reduced (from 40 to 39 in 1982, from 39 to 35 in 2000-2). The US has 40 hours/week and no mandatory paid vacation over the full period.

Source: OECD database online (series annual hours of work of dependent workers). 

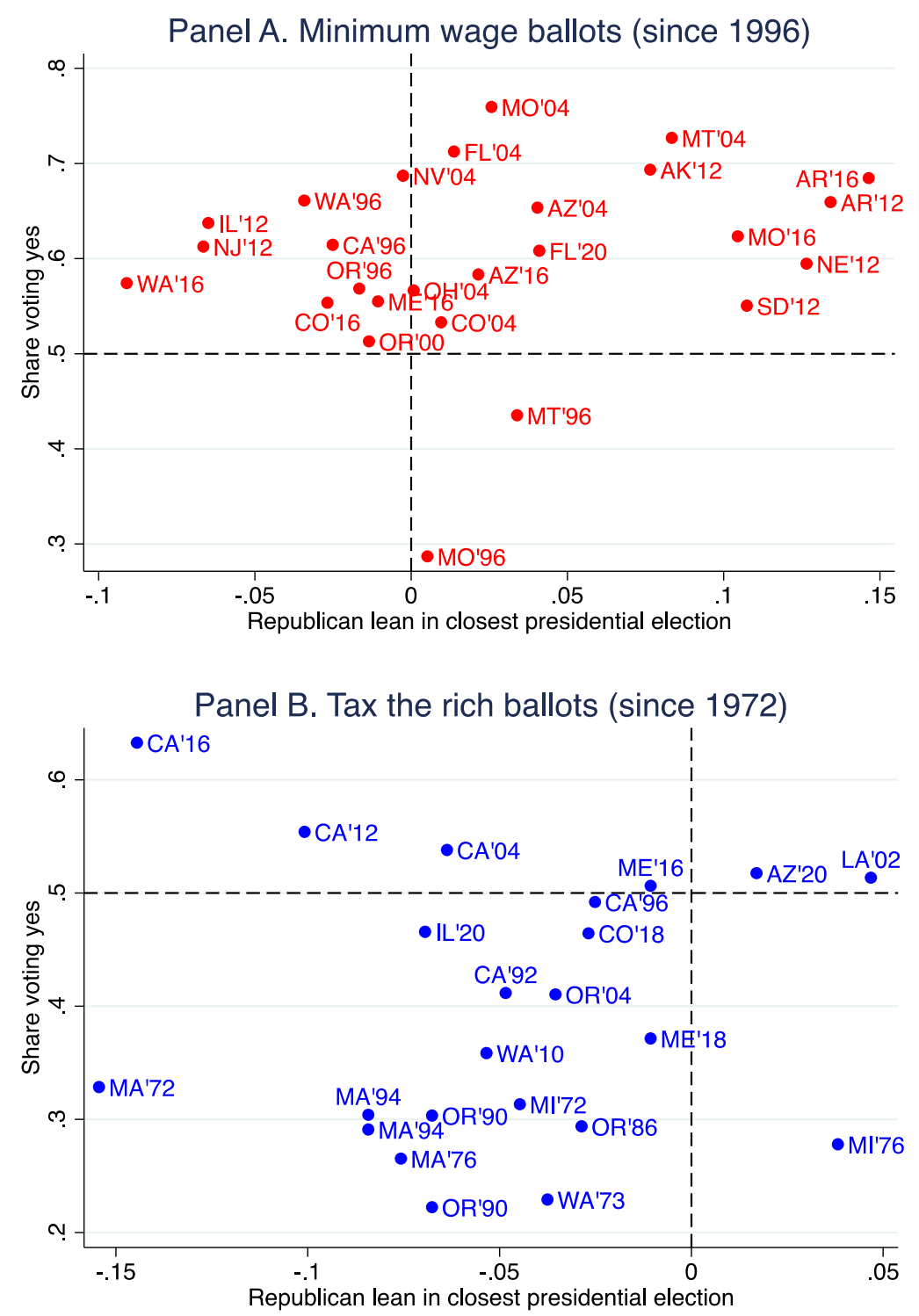

Figure 8: Pre-tax vs. Tax Redistribution Popularity in US States Ballot Initiatives

This figure contrasts the popularity of pre-tax vs. tax redistribution by looking at US state level ballot initiatives for increasing the minimum wage in Panel A (a form of pre-tax redistribution) vs. ballot initiatives to increase income taxes on upper incomes in Panel B (tax redistribution). Each ballot initiative is depicted with a dot and labelled by state and year (CA'16 = California in 2016). The y-axis is the vote share (values above .5 imply a majority of voters approved and the initiative passed). The $\mathrm{x}$-axis is the republican lean of the state in the closest presidential election (measured as percentage point difference in republican share voting in the state vs. US wide).

Panel A shows that 25 out 27 minimum wage ballot initiatives passed since 1996 including many in republican leaning states. Panel B shows that only 6 out of 23 tax the rich initiatives passed since 1972 with many initiatives defeated even in democratic leaning states.

Source: Ballots measures on minimum wage and tax increases from Ballotpedia at http://ballotpedia.org 